\title{
ABSORÇÃO DE MACRO E MICRONUTRIENTES E SINTOMAS DE CARENCIA DE MACRONUTRIENTES EM ALFACE (Lactuca satioa L.), CV. BRASIL 48 E CLAUSE'S AURÉLIA
}

\author{
LINA LEME CEZÁRIO GARCIA
}

Orientador: Prof. Dr. HENRIQUE PAULO HAAG

Dissertação apresentada à Escola
Superior de Agricultura "Luiz de
Queiroz", da Universidade de São
Paulo, para obtenção do título de
Mestre em Agronomia - Área de
Concentração: Solos e Nutrição
de Plantas.

PIRACICABA

Estado de São Paulo - Brasil

Junho - 1982 
A

Jacy de Abreu Sampaio Leme è

Jorge Leme Junior, meus pais,

OFEREÇO
A

Aderbal Cezärio Garcia, meu esposo, 


\section{AGRADECIMENTOS}

Prof. Dr. Henrique Paulo Haag pela orientação e confiança.

Engọ Agrọ Rames Elias, que ocupou, na época em que este trabalho foi realizado, o cargo de Coordenador da Coordenadoria de Assis tência Técnica Integral(CATI) da Secretaria da Agricultura do Estado de São Paulo.

Engo Agro Roberto Corte Brilho, na mesma época diretor da Divisão de Fitotecnia do Centro de Orientação Técnica (C.O.T.) da CATI, Campinas, SP.

Engo Agrọ M.S. Nozomu Makishima, Chefe da Seção de 0lericultura e Floricultura do C.O.T. da CATI, Campinas, SP.

Aos professores e funcionários do Departamento de Quĩmica da Escola Superior de Agricultura "Luiz de Queiroz", USP, Piracicaba, SP, Area de Nutrição Mineral de Plantas, pela colaboração e au$x i l$ io prestados durante a execução deste trabalho.

Ao Departamento de Agricultura e Horticultura da Escola Superior de Agricultura "Luiz de Queiroz", USP, Piracicaba, SP, na pessoa do Prof. Dr. Keigo Minami, pelas facilidades concedidas à realização do ensaio no campo. 
INDICE

Pägina

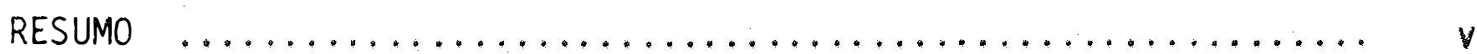

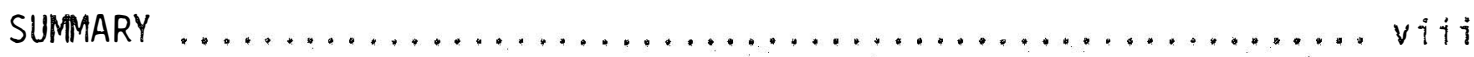

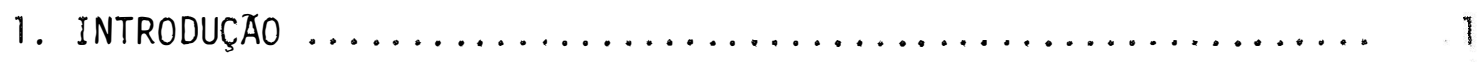

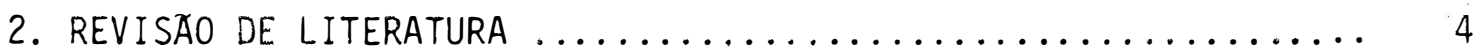

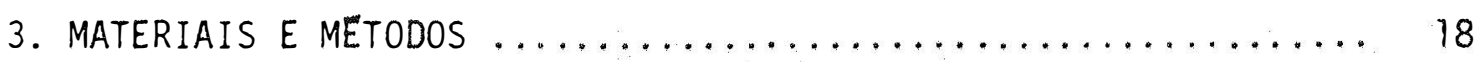

3.1. Experimento de acumulação de nutrientes em condições de campo ........................... 18

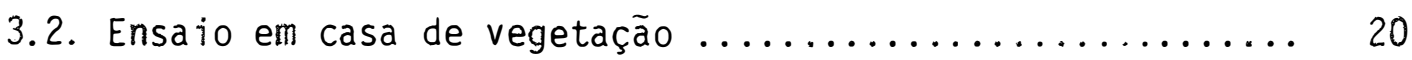

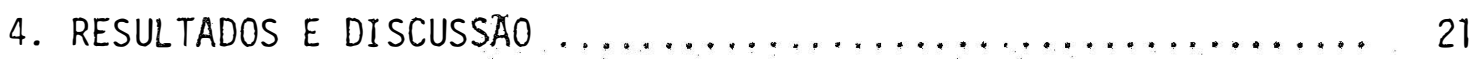

4.1. Marcha de acumulação de matēria seca e nutrientes ...... 21

4.1.1. Produção de matéria seca ................... 21

4.1.2. Acumulação de nutrientes ................. 24

4.2. Ensaio em casa de vegetação $\ldots \ldots \ldots \ldots \ldots \ldots \ldots \ldots \ldots . \ldots . \ldots$

4.2.1. Sintomatologia das deficiências ............ 49

4.2.2. Concentração dos nutrientes $\ldots \ldots \ldots \ldots \ldots \ldots \ldots . . \ldots 5$

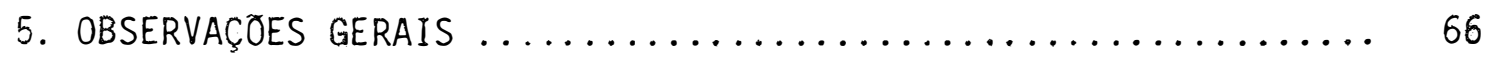

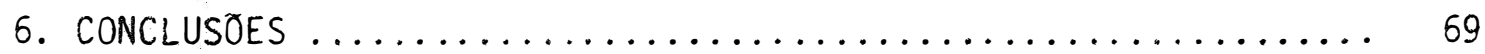

6.1. Ensaio de campo .............................. 69

6.1.1. Produção de matéria seca $\ldots \ldots \ldots \ldots \ldots \ldots \ldots . \ldots . \ldots$

6.1.2. Acumulação de nutrientes ................ 70

6.2. Ensaio realizado em casa de vegetação $\ldots . \ldots \ldots \ldots \ldots . . . .71$

6.2.1. Sintomas de deficiéncia de macronutrientes ..... 71

6.2.2. Concentração de nutrientes nas plantas ........ 71

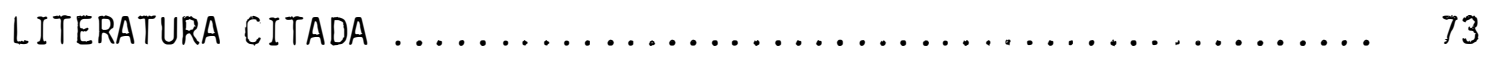




\section{ABSORÇAO DE MACRO E MICRONUTRIENTES E SINTOMAS DE CARENCIA DE MACRONUTRIENTES EM ALFACE (Lactuca sativa L.), cV. BRASIL 48 E CLAUSE'S AURELIA}

Lina Leme Cezārio Garcia Orientador: Prof.Dr. Henrique Paulo Haag

RESUMO

Com o objetivo de:

- obter e analisar o crescimento dos cultivares de alface Brasil 48 e Clause's Aurēlia;

- determinar a extração de nutrientes pelas plantas de al face, em funçăo da idade;

- obter o quadro sintomatológico das deficiēncias de macronutrientes, relacionando-os com a composição quỉmica das plantas;

Foram realizados:

- ensaio de campo, com amostragens aos $20,30,41,51,62$ e 72 dias da cultura, determinando-se a produçào de matéria seca das plantas e as concentrações de macro e micronutrientes;

- ensaio em casa de vegetaçào, com plantas de alface cultivadas em sílica e soluçăo nutritiva, sendo os tratamentos: completo, omissão de nitrogēnio, omissão de fósforo, omissào de potāssio, omissão 
de cālcio, omissão de magnésio, omissão de enxofre; acompanhando-se o desenvolvimento de sintomas de deficiēncia e determinando-se as concentrações de macronutrientes das plantas;

Chegando-se às seguintes conclusöes:

- o crescimento e a extração de nutrientes pelas plantas de alface foram lentos no inĩcio, sofrendo aceleração a partir dos 30 dias, mantendo-se intensos e não alcançando ponto de māxima acumulação atē a colheita;

- o crescimento foi semelhante para os dois cultivares, sendo a produção de matēria seca $12,75 \mathrm{~g} / \mathrm{planta}$ para o cultivar Brasil 48 e $12,52 \mathrm{~g} / \mathrm{planta}$ para o cultivar Clause's Aurēlia;

- acima de $59 \%$ da matéria seca e entre 43 e $69 \%$ dos nutrientes foram acumulados pelos dois cultivares durante os 20 dias que antecederam a colheita;

- houveram diferenças na acumulação de nutrientes, mostrando-se o cultivar Brasil 48 mais exigente;

- as quantidades de nutrientes acumuladas por planta foram, para o cultivar Brasil 48 e para o cultivar Clause's Aurélia, respectivamente: 469 e $410 \mathrm{mg}$ de nitrogēnio; $100 \mathrm{mg}$ de fösforo, 1017 e $759 \mathrm{mg}$ de potāssio; 161 e $200 \mathrm{mg}$ de câlcio; 47 e $52 \mathrm{mg}$ de magnésio; $21 \mathrm{mg}$ de enxofre; 896 e $958 \mu \mathrm{g}$ de boro, 196 e $168 \mu \mathrm{g}$ de cobre, 6800 e $5446 \mu \mathrm{g}$ de ferro, 3534 e 1025 ug de manganēs e 4462 e 2425 ug de zinco; 
- as deficiēncias de nutrientes se traduziram por sintomas típicos e facilmente identificäveis, com excessão do enxofre;

as concentrações de macronutrientes nas folhas do cultivar Brasil 48, para plantas normais e planta's com sintomas de deficiēn cia foram, respectivamente: nitrogênio: 3,37 e 1,86\%; fósforo: 0,44 e 0,16\%; potässio: 5,54 e 1,32\%; cālcio: 0,97 e 0,20\%; magnēsio: 0,35 e $0,05 \%$. Os teores de enxofre foram iguais a $0,16 \%$;

- as concentrações de macronutrientes nas folhas do cultivar Clause's Aurēlia, para plantas normais e plantas com sintomas de deficiência foram, respectivamente: nitrogēnio, 3,02 e 2,68\%; fösforo: 0,71 e 0,19\%; potássio: 7,7 e 1,54\%; cálcio: 1,47 e 0,31\%; magnésio: 0,43 e $0,10 \%$. Os teores de enxofre foram 0,24 e $0,25 \%$ 
MACRONUTRIENTS AND MICRONUTRIENTS ABSORPTION AND SYMPTOMS OF MACRONUTRIENTS DEFICIENCY IN TWO VARIETIES OF LETTUCE (Lactuca sativa L.) BRASIL 48 AND CLAUSE'S AURELIA

\author{
Candidate: Lina Leme Cezário Garcia \\ Adviser: Henrique Paulo Haag
}

SUMMARY

The experiments have the proposal to:

1) achieve and analyze both varieties growth rate;

2) determine quantitatively the amounth of nutrient extractions by the two plant varieties;

3) obtain the symptomatologic chart of macronutrients deficiencies;

4) verify the analytical level of the macronutrients in the plant under mineral deficiency conditions:

To reach such as results, the author, carried out two trials under different conditions:

1) In a commercial field where plants were collected after $20,30,41,51,62$ and 72 days old, the dry matter production as well as the concentrations of the macro and micronutrients, were determined; 
2) In a green house where seedlings were cultivated and irrigated with nutrient solutions. The treatments were, complete solutions, lacking $\mathrm{N}$ or $\mathrm{P}, \mathrm{K}, \mathrm{Ca}, \mathrm{Mg}$ and $\mathrm{S}$. Whenever the plants shown evident and clear deficiency symptoms they were harvested and analysed for the respective elements.

The results:

1) in spite of a noticed slowlyness of the growth rate and the nutrients extraction by the two varieties, at the begining they increased after 30 days. Then they keep themselves in a permanent intensively rate, not reaching the highest grade until the harvest time;

2) The growth present equalityness to both varieties being the dry matter production to Brasil 48, $12.75 \mathrm{gr} / \mathrm{pl}$. and $12.52 \mathrm{gr} / \mathrm{pl}$. to the Clause's Aurēilia;

3) Above $59 \%$ of the dry matter were accumulated by both plants along the 20 days before the harvest, while $43 \%$ to $69 \%$ of the nutrients were accumulated concerning the same period of time;

4) There were differences in the nutrient accumulations between the 2 varieties and the cultivar Brasil 48 presented the highest levels;

5) Quantitatively the amount of nutrients accumulated by the plants were: 
Brasil 48

$N \mathrm{mg}$.

P mg.

$\mathrm{k} \mathrm{mg}$.

Ca mg.

Mg mg.

$S \mathrm{mg}$.

B mg.

$\mathrm{Cu} \mu \mathrm{g}$.

$\mathrm{Fe} \mu \mathrm{g}$.

Mn $\mu g$.

Zn $\mu g$.
469

100

1.017

161

47

21

896

196

6.800

3.534

4.462
Clause's Aurēlia

410

759

200

52

958

168

5.446

1.025

2.425

6) The nutrients deficiencies were noticed by common symptoms easily identified, less sulphur;

7) The macronutrients concentrations in cultivar Brasil 48 leaves were:

$$
\text { "normal" plants }
$$

$\mathrm{N} \%$

$\mathrm{P} \%$

$\mathrm{K} \%$

$\mathrm{Ca} \%$

$\mathrm{Mg} \%$

$5 \%$
3.37

0.44

5.54

0.97

0.35

0.16 "deficient" plants

1.86

0.16

1.32

0.20

0.05 
8) The macronutrients concentrations in cultivar clause's Aurëlia leaves were:

"normal" plants

$N \%$

$\mathrm{p} \%$

$K \%$

Ca\%

$\mathrm{Mg} \%$

$\mathrm{S} \%$
3.02

0.71

7.70

1.47

0.43

0.24 "deficient" plants

2.68

0.19

1.54

0.31

0.10 
1. INTRODUÇĀO

A alface é hortaliça de grande importāncia na alimentação e saūde humanas, fonte de minerais, vitaminas e celulose, constituindose na mais popular dentre aquelas em que as folhas sào consumidas.

Na comercialização de hortaliças atravēs do CEAGESP*, no Estado de São Paulo, ocupou o 40 lugar, em valor, em 1980, significando um total de Cr\$403.930.000,00, mas esse valor dá uma pálida idéia do que representa a alface no Estado, uma vez que, ao contrārio de outras nortaliças cuja produçäo ē regionalizada e a comercialização centralizada, sua produção é bastante difundida atravēs da grande maioria dos municípios e a comercialização local dificilmente poderā ser avaliada.

Conhecendo-se os häbitos da populaçāo, todavia, sabe-se que a alface é, ao lado do tomate, a hortaliça de presença mais frequente nas mesas e a de mais fácil aquisição, dados o custo relativamente baixo e as produções locais.

* Companhia de Entreposto e Armazēns Gerais de São Pauio. 
Sua larga adaptação atual a condições climāticas diversas, o retorno rápido que proporciona ao capital empregado, a possibili dade de cultivos sucessivos no mesmo ano, a menor susceptibilidade a pragas e doenças, se comparada a outras hortaliças, e a comercialização segura tornam-na a cultura escolhida por muitos sitiantes e chacareiros.

Os novos cultivares desenvolvidos, em particular os do grupo Brasil, apresentando resistēncia a doenças aliada a produtividade e caracterīsticas aceitas pelo mercado tēm favorecido a cultura.

Por outro lado os conhecimentos de nutrição mineral da alface são relativamente escassos, faltando dados sobre a sua demanda nutricional em nossas condições, principalmente em relação aos cultivares atualmente utilizados.

Não obstante as adubações maciças que costumam ser realizadas em sua produção, a alface ē susceptĩvel ao aparecimento de sintomas de carēncia e toxicidade, tambëm por desequilíbrios nutricionais. Os fertilizantes têm elevada participação no seu custo de produção, tornando-se necessärio um melhor conhecimento das quantidades de nutrientes absorvidas e acumuladas pela cultura nas diferentes fases de desenvolvimento, que sirva de base a estudos mais detalhados de nutrição e adubação.

0 conhecimento dos sintomas de carēncia de nutrientes e necessārio a uma rāpida investigação de campo dos problemas que venham a ocorrer e à adoção de providēncias räpidas como a cultura exige. Um levantamento dos teores de nutrientes encontrados em plantas normais e deficientes serve de base à utilização da anālise foliar para diagnōstico de def ciēncias. 
0 trabalho tem por objetivo:

Obter e analisar o crescimento dos cultivares de alface Brasil 48 e Clause's Aurēlia.

Determinar as concentrações de nutrientes em função da idade da planta.

Determinar a extração de nutrientes pelas plantas e pela cultura, em função da idade.

obter o quadro sintomatolögico das deficiēncias de macronutrientes.

Verificar o efeito da omissão e presença de macronutrientes sobre a composição quỉmica da alface. 
2. REVISÃO DE LITERATURA

No finàl da década de 30, WOODMAN (1939) estudou a resposta da alface a diferentes niveis de suprimento de nitrogênio, descrevendo sintomas de caréncia desse elemento. Trabalho posterior desse mesmo autor, WOODMAN (1940) descreve sintomas de deficiência de ritrogênio e magnésio.

A partir dessa epoca, manifestou-se a preocupaçao em relacionar o estado nutricional da planta e sua produtividade com os teores de nutrientes encontrados na matéria seca, 0 trabalho de LORENS e MINGES (1942), da Universidade da Califórnia, EUA, é pioneiro nâ determinação de teores e da marcha de absorção de macronutrientes pela cultura de alface, relacionando-os com o crescimento. Esses autores obtiveram a produção de matēria verde, porcentagem de matéria seca e nutrientes(ni trogēnio, fósforo, potássio e cālcio) e a quantidade dos nutrientes removidos, em seis epocas da cultura, dos 24 anos 105 dias. Para uma produção de 31.662 libras de peso verde por acre (significando uma produção de $2.013 \mathrm{~kg} / \mathrm{ha}$ de peso seco, sendo a porcentagem de matēria seca 5,67 ) as quantidades de nutrientes removidas pela cultura foram: 47,02 1ibras/ 
acre de nitrogênio ( $53 \mathrm{~kg} / \mathrm{ha}), 6,74$ libras/acre de fösforo $(7,56 \mathrm{~kg} / \mathrm{ha}$ ), $116,71 \mathrm{ibras} / \mathrm{acre}$ de $\mathrm{K}_{2} \mathrm{O}(108,6 \mathrm{~kg} / \mathrm{ha}$ de potássio) e 30,02 1ibras/acre de $\mathrm{CaO}(24 \mathrm{~kg} / \mathrm{ha}$ de cálcio $)$.

MIDGLEY e DUNKLEE (1946), da Estação Experimental de Agrị cultura de Vermont, EUA, determinaram os teores de boro em plantas de alface, encontrando em plantas deficientes, que apresentavam sintomas des critos como "yelow heart" e, ocasionalmente, forma de roseta, 14 a 18 ppm, e nas plantas sadias, $35 \mathrm{ppm}, 0$ que os levou à conclusão de que seria fä cil a determinação da deficiência de boro atravēs de anālises foliares.

BEAR et alie (1949) realizaram um levantamento dos teores de macro e micronutrientes na matéria seca de alface de culturas de nume rosos estados dos EUA, concluindo serem os valores encontrados para fösforo relativamente constantes, apresentando as demais tendencias definidas, como os casos de boro, ferro, molibdênio, cobre e cobalto, com teores crescentes de leste a oeste, e manganês, com teores decrescentes nessa mesma direção.

Trabalhando com alface em solos formados sobre serpentina, VLAMIS (1949), da Universidade da Califörnia, EUA, descreve sintomas como aparência de roseta, enrolamento de folhas, baixa produção, paralisação do crescimento das folhas mais novas e pintas escuras ao longo da margem das folhas. As anālises dos tecidos das plantas mostraram ser os sintomas descritos reflexo do baixo teor de cálcio das mesmas 10,26 a $0,37 \%$ nas plantas com sintomas e $1,55 \%$ nas normais), em consequência do baixo grau de saturação do complexo de troca do solo estudado, por cālcio. 
HAMILTON e BERNIER (1955), no Canadā, determinaram a produção de matéria seca, os teores e as quantidades extraídas de macro e micronutrientes pela cultura de alface por ocasião da colheita, relacionando as quantidades removidas atravēs da produção econômica e as remanescentes no solo sob a forma de resíduos. A produção econômica obtida foi de $1.200 \mathrm{~kg} / \mathrm{ha}$ de matéria seca, e os resíduos produzidos acima do so 10 somaram $1.900 \mathrm{~kg} / \mathrm{ha}$. As quantidades totais extraídas pela parte aerea (somando-se produção econōmica e resīduos) foram: $88,5 \mathrm{~kg} / \mathrm{ha}$ de $\mathrm{ni-}$ trogēnio, $16,7 \mathrm{~kg} / \mathrm{ha}$ de fósforo, $166,4 \mathrm{~kg} / \mathrm{ha}$ de potāssio, 40,8 kg/ha de cālcio, 18,0 kg/ha de magnēsio, 172,7 g/ha de manganēs, $229,6 \mathrm{~g} / \mathrm{ha}$ de zinco, 25,6 g/ha de cobre e $61,5 \mathrm{~g} / \mathrm{ha}$ de boro.

Relacionando suprimento de nutrientes, produção e teores encontrados nas plantas, o trabalho de LAMBETH (1953) estuda particularmente ó problema do potāssio, em relação a diferentes níveis de magnēsio e nitrogēnio, enquanto a sërie de trabalhos publicados por GOODALL e colaboradores, da Universidade de Melbourne, Austrālia, no perīodo de 1955 a 1958, aborda as interações nutricionais e o diagnōstico de deficiēncias em alface.

GOODAL et alii (1955) descrevem os sintomas de deficiēncia de nitrogēnio, fósforo e potāssio, apresentando-se as plantas deficientes em nitrogēnio pequenas e pālidas, com as folhas amarelecidas; as deficientes em fōsforo, menores em tamanho e com coloração amarelada, as deficientes em potāssio, com folhas grossas e arredondadas, em a tguns ca sos com forma de coração, ou gancho em estāgios mais tardios, com as bor das planas e coloração verde escura, fosca, com as nervuras pāilidas. As plantas deficientes em quaisquer desses nutrientes não formaram cabeça. 
SLATER e GOODALL (1957) encontraram as maiores produções de alface a niveis intermediários de suprimento de nitrogēnio, a que cor responderam teores de 3,32 a $3,66 \%$ desse nutriente. GRANT LIPP e GOODALL (1958) obtiveram as melhores produções sob os mais elevados nỉveis de suprimento de fösforo, correspondendo a teores de fösforo em torno de $0,5 \%$.

Ainda nessa linha de trabalhos, hä o de PARUPS (1958), no Canadä, que encontrou, em diferentes solos, diferentes niveis de nutrien tes nas plantas, correspondendo a adubações equivalentes e, num mesmo so 10, diferentes teores na planta correspondendo a diferentes adubações. Os teores encontrados variaram de 0,333 a $0,693 \%$ de fósforo e 4,21 a $8,62 \%$ de potāssio.

SMITH e SCAIFE (1972), da Universidade de Cambridge, trabalhando com diferentes tipos de solo e diferentes niveis de suprimento de fósforo, encontraram teores de fósforo na planta de alface variando entre 0,18 e $0,74 \%$, definindo como concentração ótima na primeira coTheita a de $0,6 \%$.

Relacionando teores de nutrientes nas plantas e sintomas de deficiēncia temos, alēm do trabalho jā citado de MIDGLEY e DUNKLEE (1946) com boro, o trabalho de HERNANDO e SANCHEZ CONDE (1964) do Instituto de Edafologia e Biologia Vegetal de Madri, Espanha, com alface romana, em que são descritos sintomas de carência de macronutrientes e determinados os teores em plantas normais e deficientes. A deficiēncia de nitrogênio caracterizou-se pelo amarelecimento das folhas velhas, com posterior desensolvimento de coloração marron e seca das fol a 
de fósforo, pela coloraçào rosada da nervura central e verde escura das folhas, que sao mais lisas; a de potássio por comprimento exagerado dos caules, e manchas amarelo-marrons nos bordos das folhas, principiando pelas mais velhas e terminando com a seca das folhas. Já a deficiência de cálcio se manifestou nos brotos, as folhas mostrando-se muit enrugadas, de coloraçào verde muito intensa, podendo as extremidades das folhas dos brotos adquirirem coloraçào marron esverdeada quase negra. A deficiência de magnēsio se caracterizou por manchas amarelas interner vais. As plantas mais sensiveis à falta de umidade foram as carentes em cälcio, seguindo-se as deficientes em potāssio.

ROORDA VAN EYSINGA et alii (1971), na Noruega, apresentaram trabalho extenso com descrição de sintomas de deficiência e toxicida de de macro e micronutrientes, relacionados a teores de nutrientes encon trados na matëria seca. Os sintomas de deficiēncia, resumidamente, são: nitrogênio: amarelecimento da folhagem, palidez e queda das folhas mais velhas, denso sistema radicular; fósforo: plantas achatadas e em forma de roseta, podendo as folhas apresentarem coloração verde escura, purpūrea ou vermelho bronzeada; potássio: as folhas são verde escuras e menos crespas que o normal, podendo tornar-se pecioladas, arredondadas ou em forma de coração, com manchas cloróticas desenvolvendo-se na extremidade das folhas mais velhas, coalescendo e tornando-se necróticas; cālcio: folhas com crescimento aberto em roseta, folhas mais novas mais escuras e mais enrugadas que o normal, apresentando lesões de coloração marron a cinza irregularmente distribuidas nas margens das folhas mais novas, que coalescem e levam a folha a morrer da extremidade e margens para den tro; magnésio: folhas mais velhas mostram descoloração amarelada, que 
se espalha das margens para dentro, entre as nervuras; enxofre: coloração amarelo esverdeado, folhas menos crespas, mais grossas e rijas que o normal, folhas mais velhas escuras e baças.

PEREZ MELIAN et alii (1977), no Internacional Centre for Hydroponics, Espanha, publicou trabalho sobre a anālise foliar como instrumento no diagnóstico de deficiencia e toxicidade de macronutrientes. Nesse trabalho descreve sintomas, determina teores e conclui pela oportunidade ou não do uso da anālise foliar para cada nutriente. Os autores descrevem a deficiēncia de cálcio como acarretando um enrugamento e acastanhamento, principalmente nas extremidades das folhas novas, e nas folhas mais velhas, encrespamento e forma de guarda-chuva. Tendo os sintomas para deficiēncia acentuada visiveis e definidos, e sendo os teo res das plantas com deficiēncia leve semelhantes aos das plantas normais, não recomendam os autores o uso da anālise foliar para diagnóstico de deficiēncia de cálcio. Para nitrogènio e potássio os autores não obtiveram sintomas visuais, sendo a redução na produção de 15 a $30 \%$, e con cluiram que, para diagnóstico de deficiências acentuadas, a anālise foliar poderia ser usada, pois foram encontradas diferenças nos teores de nitrogēnio das plantas. Em relação ao fósforo, os sintomas de deficiēncia foram coloração pūrpura, de antocianina, nas folhas, e a anālise foliar seria indicada para diagnóstico de deficiēncia somente em estágios iniciais de crescimento, uma vez que as plantas deficientes não chegaram a produzir.

NISHIMOTO et alii (1977), da Universidade do Hawai, em relação a fósforo, e ADAMS (1978) na Inglaterra, em relação a nitrogênio 
e potássio, determinaram os teores desses elementos em plantas de alface que alcançaram mäxima produção, encontrando valores de $0,35 \%$ de fösforo, $5 \%$ de nitrogênio e $8 \%$ de potássio. ADAMS (1978) encontrou teores de 1,5 a $2,5 \%$ de nitrogênio em planitas deficientes.

0 nutriente objeto de maiores estudos isoladamente ou jun tamente com outros è o cālcio. Alēm do trabalho desenvolvido por VLAMIS (1949), outros autores dedicaram-se ao assunto.

STRUCKMEYER e TIBBITS (1965), da Universidade de Wisconsin, EUA, descrevem os sintomas de deficiēncia de cālcio, distinguindo-os dos de deficiēncia de boro principalmente pelo derramamento de "lātex" que ocorre nesta ūltima, ocasionando queimaduras diferentes do "tipburn" clās sico. Nas plantas carentes em cálcio, segundo esses autores, desenvolvem-se lesões escuras primeiramente prōximo às margens da base das foThas e depois na lâmina inteira, coalescendo e resultando em necrose. In ternamente os sintomas descritos sao o colapso das cëlulas da epiderme e mesōfilo entre os feixes vasculares, hipertrofia das cēlulas do parēnquima lacunoso causando esmagamento das cēlulas adjacentes, obstrução de vasos do xilema, permanecendo normais os vasos lactiferos.

Na deficiēncia de boro, os autores constataram pintas mar ron-pardacentas visiveis primeiramente ao longo da margem inferior das folthas mais novas, que se estenderam ao longo das margens das folhas e às vezes exudação de lätex para a superfície externa da folha. Ocorreu também má formação e enrugamento do tecido entre as veias. As folhas adquiriram uma forma recortada e o crescimento da porção distal foi inibido. Considerāveis alterações anatōmicas foram constatadas na de- 
ficiēncia de boro, sendo o fator de distinção o rompimento dos vasos latîferos nas áreas desorganizadas e o derramamento de látex.

THIBODEAU e MINOTTI (1969) efetuaram o controle de "tipburn" em alface atravēs da pulverização foliar com $\mathrm{Ca}\left(\mathrm{NO}_{3}\right)_{2} \mathrm{Ou} \mathrm{CaCl}_{2}$. elevando o teor de cálcio das folhas e provando a relação existente entre esse sintoma e a deficiēncia de cálcio.

LEH (1970), em Berlim, Alemanha Ocidental, relacionou a incidência de "tipburn" a relações $\frac{K}{C a} \quad \frac{N}{C a}$ e $\frac{K \times N}{C a}$ elevadas, devidas a aplicações crescentes de NPK ou NK, constatando menor teor de cālcio nas folhas das plantas submetidas a suprimentos mais elevados de nitrogènio e potāssio.

Em trabalhos recentes, SANCHEZ CONDE (1980) estudou 0 efeito do meio nutritivo com baixos teores de cálcio sobre a planta de alface, constatando reações da planta tentando manter suas relações catiōnicas e aniōnicas, assim como as somas parciais de elementos, dentro de valores semelhantes aos das plantas normais, o que trouxe como consequência diferente teor de elementos minerais nas plantas.

CAROLUS (1975), em experimento fatorial de calagem e adulação, encontrou um teor de $0,52 \%$ de cálcio nas plantas, correspondendo a uma produção relativa de 113, obtida em solo com pH 6,5, e um teor de $0,38 \%$ de cālcio correspondendo a uma produção relativa de 90 , a um pH 5,5.

Em relação à marcha de absorção e acumulação de nutrientes, além do trabalho de LORENS e MINGES (1942), e do de HAMILTON e BERNIER (1955), temos os de ZINK e YAMAGUCHI (1962) e FERNANDES et alii (1971). 
ZINK e YAMAGUCHI (1962) determinaram os teores e as quantidades de macronutrientes acumuladas por culturas de alface em diversas épocas, relacionando-as com o crescimento. Por ocasião da primeira colheita, as quantidades acumuladas foram, em média, por acre: 95 libras de nitrogēnio, 27 libras de $\mathrm{P}_{2} \mathrm{O}_{5}, 208$ libras de $\mathrm{K}_{2} \mathrm{O}, 33$ libras de cālcio, 12 libras de magnēsio e 9 libras de sōdio, que equivalem a 106,5 $\mathrm{Kg} / \mathrm{ha}$ de nitrogēnio, $13,2 \mathrm{~kg} / \mathrm{ha}$ de fósforo, $193,5 \mathrm{~kg} / \mathrm{ha}$ de potässio, $37 \mathrm{~kg} / \mathrm{ha}$ de cālcio, $13,5 \mathrm{~kg} / \mathrm{ha}$ de magnésio e $10 \mathrm{~kg} / \mathrm{ha}$ de södio.

Os autores constataram que a forma das curvas de absorção de nitrogênio, fósforo e potāssio sao bem semelhantes à de produção de matéria verde, sendo a acumulação bastante lenta na primeira fase do crescimento. Setenta por cento do nitrogēnio, fósforo e potássio acumulados o foram nos 21 dias de máxima taxa de crescimento imediatamente anteriores à primeira colheita. Setenta por cento do peso verde foi igualmente incorporado nos 21 dias que antecedem a colheita, e $36 \%$ nos ū timos sete dias.

FERNANDES et alii (1971) no Brasil, determinaram teores, estudaram o crescimento e estimaram as quantidades de nutrientes acumula das por cultura de alface em $23,2 \mathrm{~kg} / \mathrm{ha}$ de nitrogênio, $4,4 \mathrm{~kg} / \mathrm{ha}$ de fósforo, $50,9 \mathrm{~kg} / \mathrm{ha}$ de potássio, 13,3 kg/ha de cālcio, 3,2 kg/ha de magnēsio e $3,0 \mathrm{~kg} / \mathrm{ha}$ de enxofre, para uma produção de $969 \mathrm{~kg} / \mathrm{ha}$ de matēria se ca. Concluiram os autores ser a absorção lenta até os 48 dias, e que a absorção de nutrientes acompanha o crescimento das plantas.

GARDNER e PEW (1979) estudaram a acumulação de nitrogēnio a baixas temperaturas, por alface, encontrando de 100 a $110 \mathrm{~kg} / \mathrm{ha}$ de 
nitrogēnio absorvidos aos 120-130 dias (colheita).

PANDITA e ANDREW (1967), da Universidade de Alberta, Canadā, encontraram uma correlação negativa entre o teor de fösforo na foTha de alface e o nümero de dias necessārios para maturação.

A tabela 1 contëm os teores de nutrientes de plantas de alface determinados pelos autores jā citados nesta revisão de literatura. 


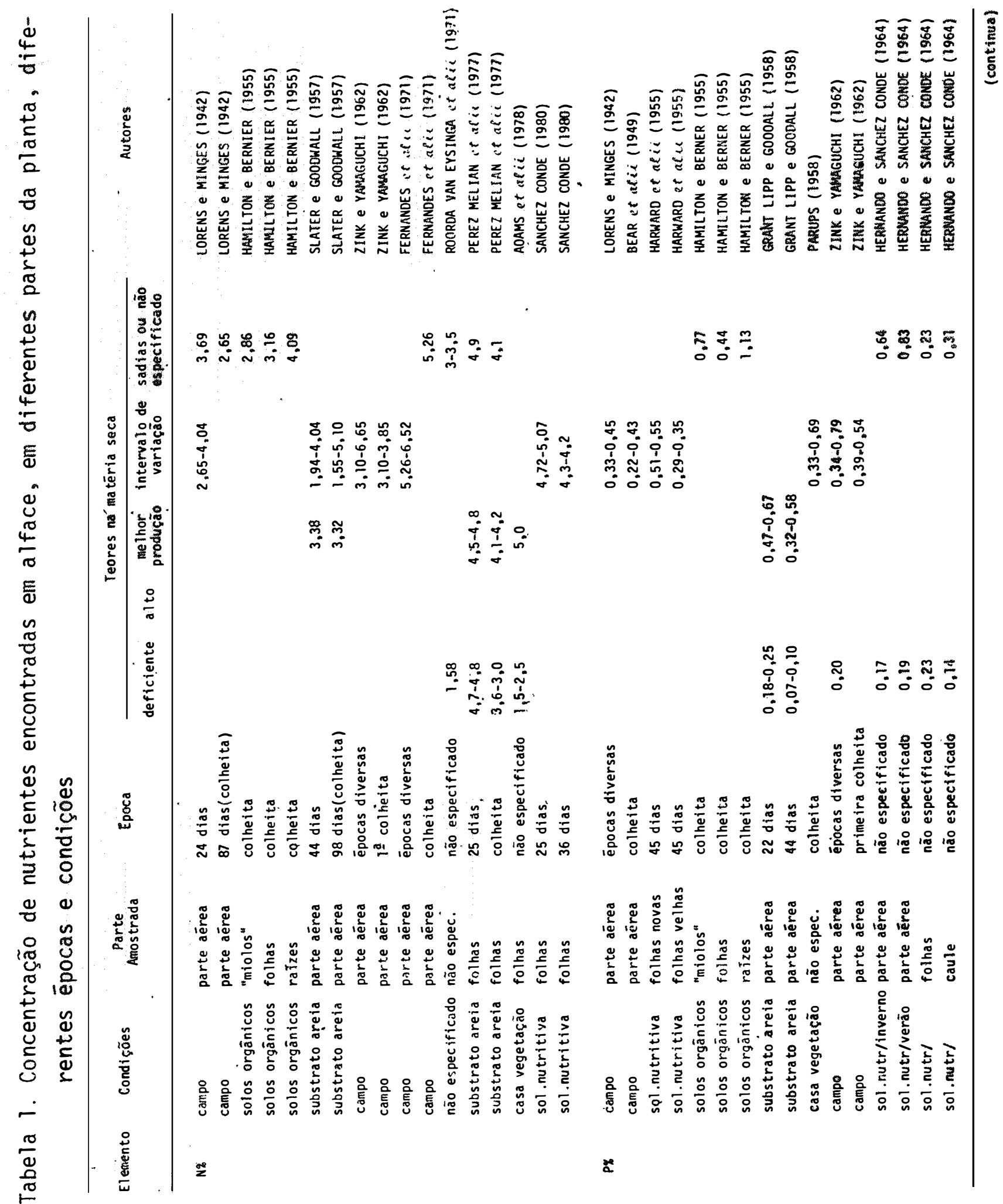




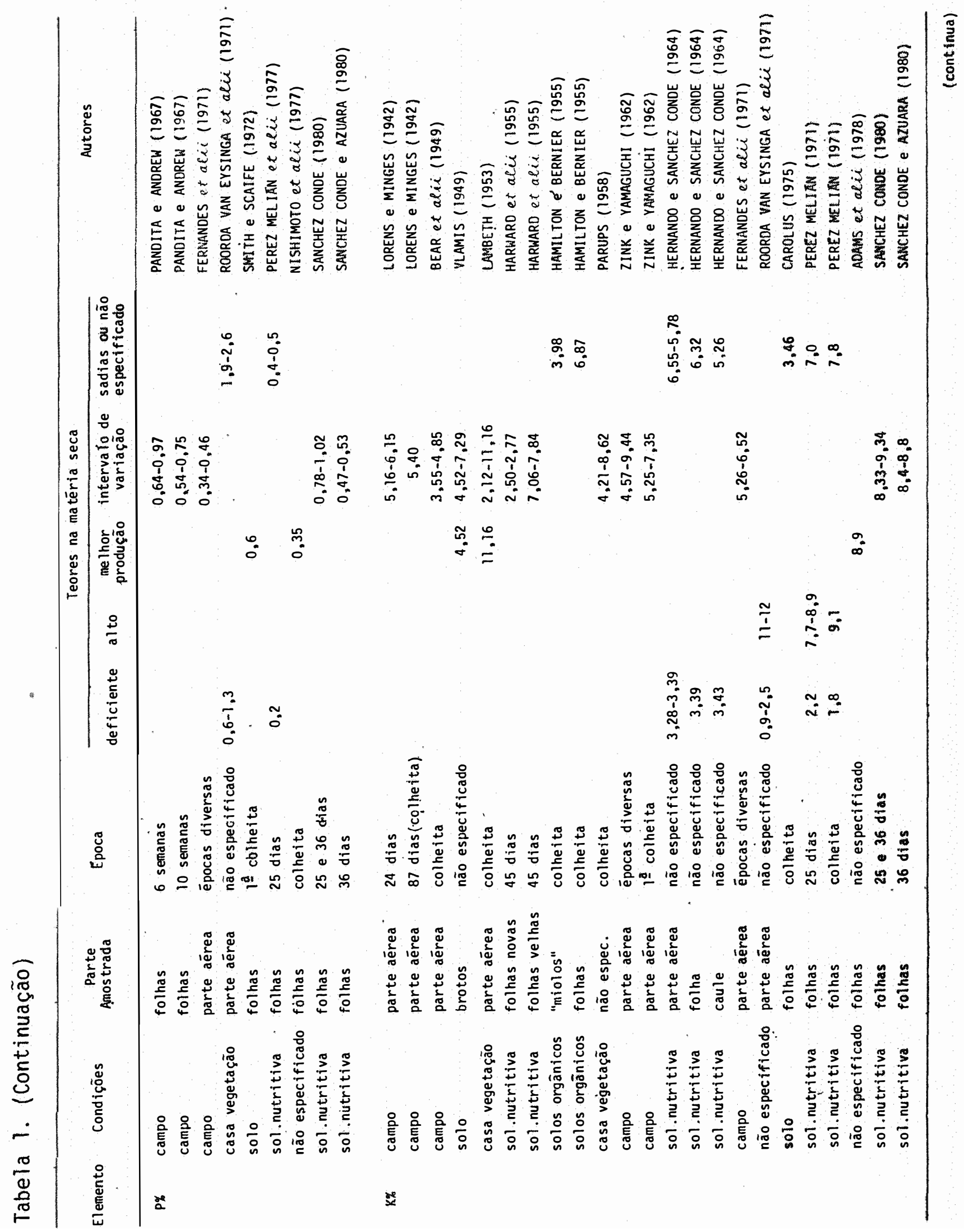




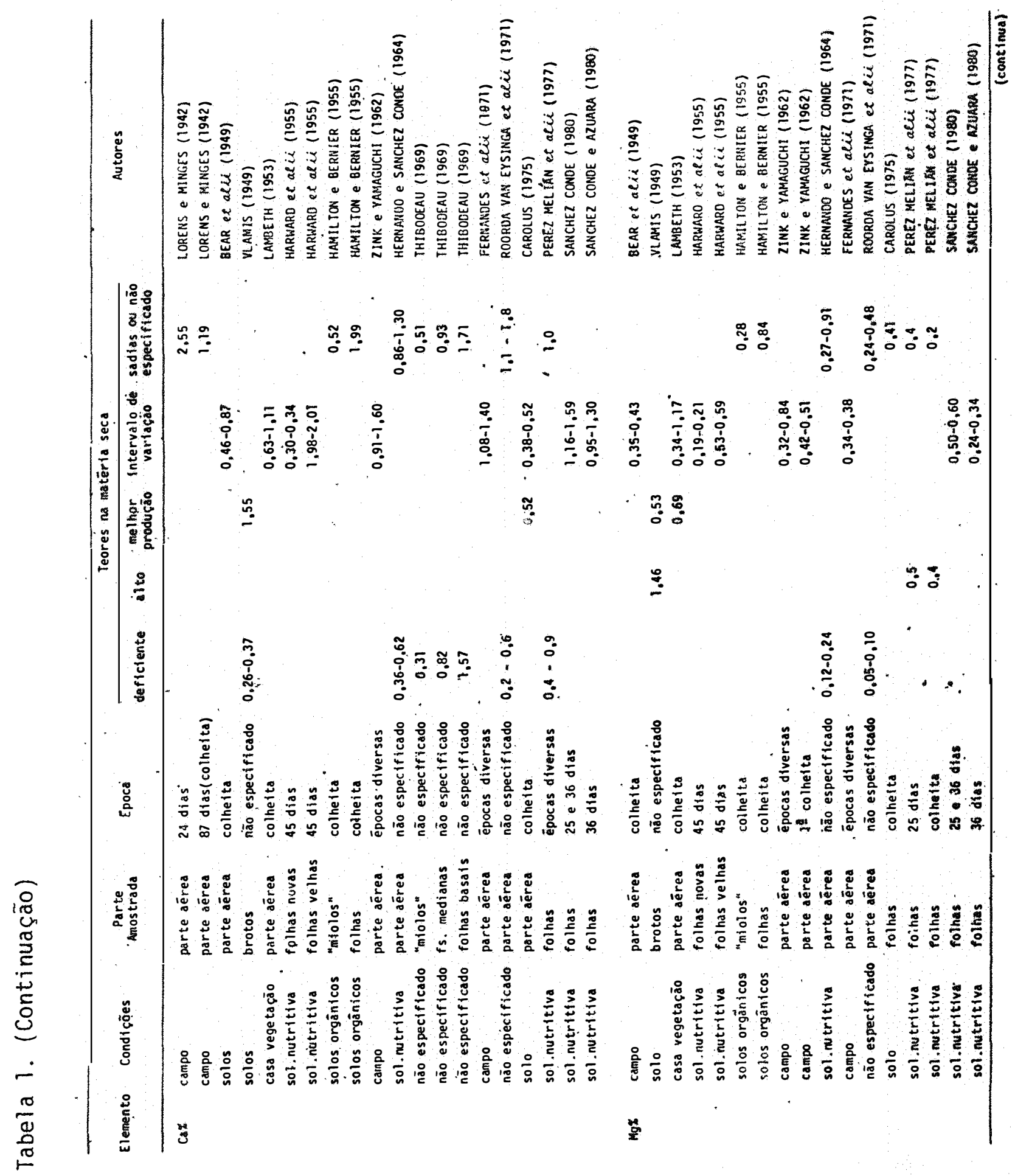




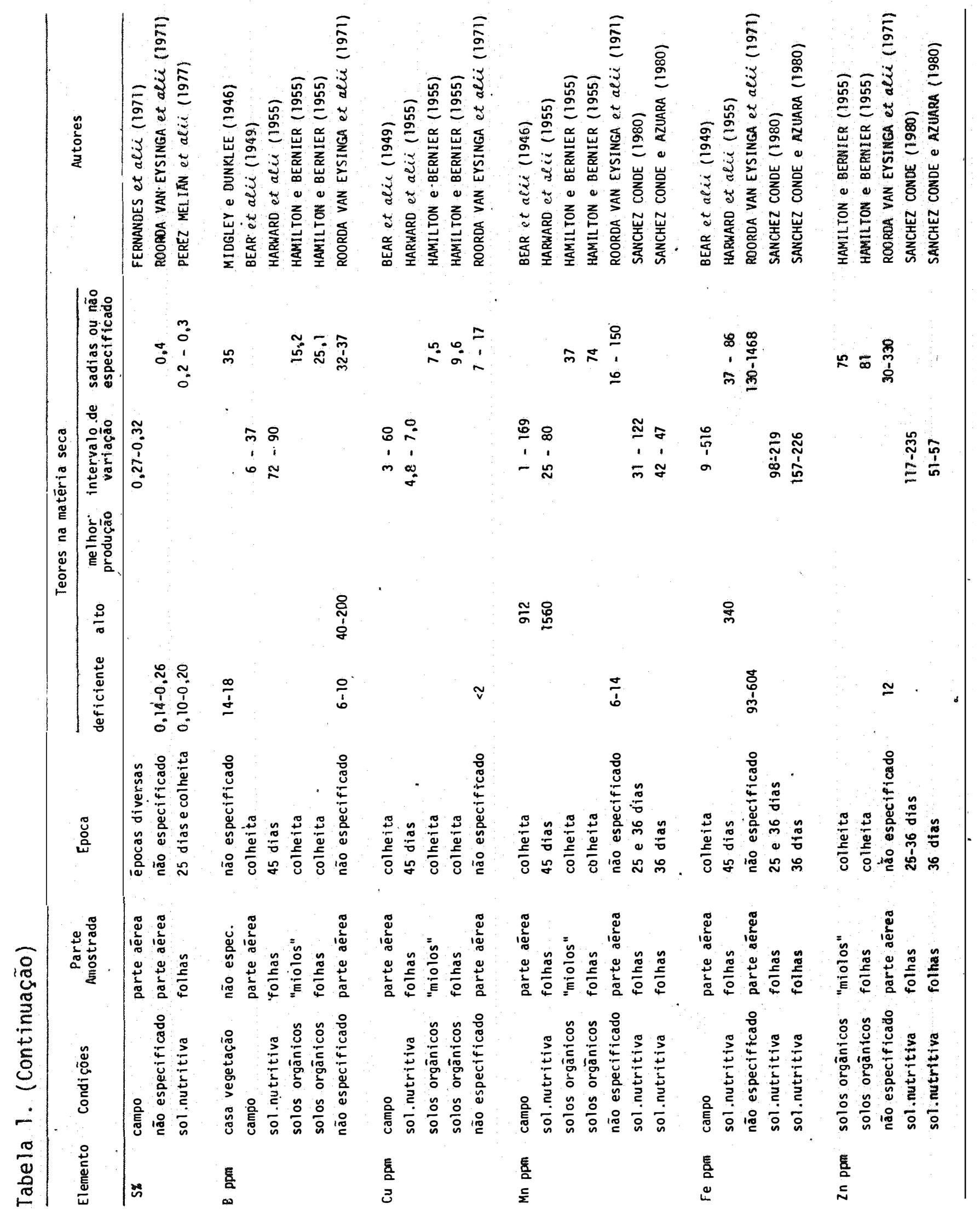




\section{MATERIAIS E METODOS}

Foram utilizados os cultivares de alface (Lactuca sativa L.) Brasil 48 e Clause's Aurēlia.

\subsection{Experimento de acumulação de nutrientes em condições de campo}

0 ensaio foi instalado no campo experimental do Departamento de Agricultura e Horticultura da Escola Superior de Agricultura "Luiz de Queiroz", USP, no município de Piracicaba, Estado de São Paulo, cujas coordenadas geogräficas são, segundo a Enciclopédia dos Municĩpios Brasileiros (1957): Latitude S: $22^{\circ} 41^{\prime} 31^{\prime \prime}$, Longitude WG: $47^{\circ} 38^{\prime} 01^{\prime \prime}$ e Altitude: 540 metros.

O clima local é classificado por SETZER (1956) como mesotérmico Cwa subtropical úmico, com estiagem no inverno, sendo a temperatura do mès mais quente superior a $22^{\circ} \mathrm{C}$, e a do mês mais frio inferior a $18^{\circ} \mathrm{C}$.

O solo utilizado é classificado por RANZANI et alii (1966) como Terra Roxa Estruturada, sērie "Luiz de Queiroz", e vem sendo 
cultivado com hortaliças a mais de cinquenta anos consecutivos. As suas caracterīsticas quĩmicas enquadram-se, segundo WUTKE (1972), nos seguintes parāmetros: pH-medianamente ācido; $\mathrm{C} \%$-alto; $\mathrm{PO}_{4}^{+3}$-alto; $\mathrm{K}^{+}$-mēdio; $\mathrm{Ca}^{+2}$-muito al to; $\mathrm{Mg}^{+2}$-médio; e $\mathrm{Al}^{+3}$-aceitável.

As mudas foram obtidas em sementeiras, e transplantadas para canteiros aproximadamente vinte dias apös a germinação. 0 espaçamento adotado foi de trinta por vinte e cinco centimetros, em canteiros que ocupavam cerca de $70 \%$ do terreno, correspondendo a uma população teō rica de 95000 plantas/hectare.

A adubação usada constou de aplicação de $20 \mathrm{~g}$ por metro linear da fórmula 4-14-10, por ocasião do transplante. Aos 20 e aos 40 dias apōs o transplante foi aplicado $5 \mathrm{~g}$ de sulfato de amönio por planta.

A cultura foi irrigada sempre que necessārio.

As amostragens foram feitas por ocasião do transplante, e depois a intervalos de dez dias aproximadamente. Cada amostra constou de um número variável de plantas, dependendo do desenvolvimento da cultura, mas com um mỉnimo de uma planta por cultivar e quatro repetições.

As plantas foram cortadas rente ao solo, lavadas de acordo com o recomendado por SARRUGE e HAAG (1974). Secas em estufa com cir culação forçada de ar a $75^{\circ} \mathrm{C}$, pesadas, moîdas e submetidas à anālise quĩ mica, segundo os métodos descritos em SARRUGE e HAAG (1974). 


\subsection{Ensaio en casa de vegetação}

Mudas de alface com aproximadamente vinte dias foram transplantadas para vasos com capacidade de $3 \mathrm{~kg}$, contendo silica finamente moỉda, e irrigadas com solução nutritiva completa (SARRUGE, 1970) durante 25 dias.

Apös esse período foram iniciados os tratamentos completo, omissão de nitrogênio, omissão de fōsforo, omissão de potássio, omis sao de cālcio, omissão de magnésio e omissão de enxofre, empregando-se as soluções recomendadas por SARRUGE (1970). O delineamento estatĩstico foi inteiramente casualizado com 4 repetições.

As plantas foram irrigadas duas vezes por dia com as soluções e o seu desenvolvimento foi acompanhado, e anotados os sintomas à medida em que estes se manifestavam.

Uma vez evidenciados os sintomas, as plantas foram coletadas, separadas em folhas novas, folhas velhas, caule e raĩzes. 0 material coletado foi lavado, segundo as recomendaçōes de SARRUGE e HAAG (1974), seco em estufa a $75^{\circ} \mathrm{C}$, moído e analisado para N, P, K, Ca, Mg e $S$, segundo os métodos descritos em SARRUGE e HAAG (1974). 
4.1. Marcha de acumulação de matēria seca e nutrientes

4.1.1. Produção de matéria seca

A produção de matéria seca expressa o crescimento das plantas; e os dados obtidos em relação às plantas e cultura de alface estudados no presente trabalho encontram-se na tabela 2.

Não foi encontrada diferença significativa entre os cultivares Brasil 48 e Clause's Aurēlia, em relação à produção de matēria se ca, a nao ser para a quinta amostragem, aos 62 dias da cultura.

A produção final de matēria seca por planta foi pouco superior à observada por FERNANDES et alii (1971) para o cultivar Vitōria de Santo Antão, nas condições de Piracicaba, e pelo menos três vezes menor que as relatadas por LORENZ e MINGES (1942) e ZINK e YAMAGUCHI (1962), para cultivares diversos, nos EUA. 
Tabela 2. Produção de matéria seca por cultura de alface, cultivares Brasil 48 (B.48) e Clause's Aurēlia (C.A.), em 6 épocas de amostragem. Médias de 4 amostras. População: 95000 plantas/hectare

\begin{tabular}{|c|c|c|c|c|c|c|c|}
\hline & & \multicolumn{6}{|c|}{ Dias } \\
\hline & & 20 & 30 & 41 & 51 & 62 & 72 \\
\hline \multirow[t]{2}{*}{$\mathrm{g} / \mathrm{pl}$} & B. 48 & 0,08 & 0,18 & 1,37 & 4,36 & $7,91 *$ & 12,75 \\
\hline & C.A. & 0,11 & 0,29 & 1,78 & 5,13 & $9,15^{\star}$ & 12,52 \\
\hline \multirow[t]{2}{*}{$\mathrm{Kg} / \mathrm{ha}$} & B. 48 & 7,60 & 17,10 & 130,15 & 414,20 & 751,40 & 1211,20 \\
\hline & C.A. & 10,45 & 27,55 & 169,10 & 487,30 & 869,20 & 1189,40 \\
\hline$\%$ acumu & B. 48 & 0,6 & 1,4 & 10,7 & 34,2 & 62,0 & 100,0 \\
\hline lada & C.A. & 0,9 & 2,3 & 14,2 & 40,9 & 73,1 & 100,0 \\
\hline \multicolumn{2}{|c|}{$\begin{array}{l}\text { F. cultivar } \\
\text { eppoca }\end{array}$} & \multicolumn{2}{|c|}{$\begin{array}{c}\text { n.s. } \\
223,64\end{array}$} & \multicolumn{4}{|c|}{ CDE $-5-5,09 * *$} \\
\hline DMS & & \multicolumn{2}{|l|}{ cultivar } & \multicolumn{3}{|c|}{$1,15(5 \%)$ e $1,78(1 \%)$} & \\
\hline (Tukey) & \multicolumn{3}{|c|}{ época } & $\begin{array}{l}1,4 \\
1,5\end{array}$ & \multicolumn{2}{|c|}{$(5 \%)$ e $3,30(1 \%)$} & \\
\hline c.v. & 20,6 & & & & & & \\
\hline
\end{tabular}

Equações de regressão

$$
\text { B.48 } \quad \begin{aligned}
y & =1,011-1,586 x+0,592 x^{2} \\
\text { C.A. } \quad y & =3,098-4,553 x+1,764 x^{2}-0,124 x^{3} \\
& y=\text { produção de matéria seca g/planta } \\
x & =\text { idade em dias }
\end{aligned}
$$

\begin{tabular}{lcc}
\hline & & C.A. \\
\cline { 2 - 3 } & dias & $9 /$ planta \\
ponto de máxima & 92 & 16,28 \\
ponto inflexão & 58 & 8,05 \\
\hline
\end{tabular}


A produção final de matéria seca por hectare foi, no presente trabalho, cerca de $20 \%$ superior à observada por FERNANDES et alii (1971) e representou de 60 a $35 \%$ da constatada nos EUA pelos autores já citados.

De modo semelhante ao encontrado em outros trabalhos, o crescimento inicial foi lento, ocorrendo depois uma aceleração que se deu por volta dos trinta dias.

As taxas máximas de crescimento observadas aproximaramse das constatadas por FERNANDES et alii (1971) no trabalho jä citado. ZINK e YAMAGUCHI (1962) observaram taxas bastante superiores, entre 3 e 4 gramas de matéria seca acrescentada por planta e por dia, representando um incremento diārio de mais de duzentos quilos de matéria seca por hectare, enquanto o máximo observado em nossas condições foi de 46 quilos/hectare.

As taxas de incremento na matéria seca por planta foram crescentes, até um mäximo de 0,484 gramas/dia, para o cultivar Brasil 48, alcançado entre o 620 e o 720 dias da cultura, O cultivar Clause's Aurélia apresentou uma taxa diāria máxima de 0,402 gramas/planta entre o 510 e o 620 dia, e no período seguinte um crescimento ligeiramente inferior $(0,337$ gramas/planta).

Os padrões de crescimento observados neste trabalho dizem respeito apenas ao crescimento vegetativo, tendo sido as plantas colhidas no ponto de comercialização para consumo "in natura", o que ocorreu antes que a taxa de crescimento declinasse, ou declinasse acentuadamente. 
Desprezando-se as diferenças devidas a material genético e condições ambientais, e a ciclo vegetativo, o padrão de crescimento observado foi semelhante ao analisado por ZINK e YAMAGUCHI (1962), com aproximadamente $66 \%$ do total da matéria seca, para o cultivar Brasil 48, e $59 \%$, para o cultivar clause's Aurélia acrescidos às plantas nos 20 dias que antecederam a colheita. Nos ūltimos dez dias da cultura foram acres cidos, respectivamente, 38 e $27 \%$. Esse padrão é diferente do observado por LORENS e MINGES (1942) e do descrito por FERNANDES et alii (1971), tendo nestes trabalhos a taxa de incremento na matéria seca caído mais acentuadamente no final da cultura, com acréscimo de apenas $20 \%$ do total nos ūitimos 18 e 15 dias, respectivamente.

\subsubsection{Acumulação de nutrientes}

A marcha da absorção de nutrientes pela cultura de alface neste trabalho acompanhou, em linhas gerais, a da produção de matéria seca, sendo lenta no início e sofrendo aceleração apōs os 30 dias.

Excetuando-se o enxofre e o nitrogēnio, para o cultivar Clause's Aurélia, as quantidades de macronutrientes absorvidas nos onze dias que antecederam a colheita representaram de 25 a $36 \%$ do total acumu lado pelas plantas. 0 nitrogénio e o enxofre, no cultivar mencionado, ti veram absorção mais precoce, tendo sido realizada apenas 18 e $15 \%$ do total, respectivamente, no período considerado.

Nesse periodo a acumulação de micronutrientes apresentou maior variação. 0 zinco mostrou-se de absorção bastante tardia, tendo 64,5\% (cultivar Brasil 48) e 52\% (cultivar Clause's Aurēlia) do total 
acumulado nos ūltimos onze dias. Para boro, cobre, ferro e manganês, a absorção nesse período representou de 22,3 a $46,2 \%$ do total.

Para os $\bar{u} 1$ timos vinte e um dias (do 510 ao 720 dia) o enxofre foi, dentre os macronutrientes, o que apresentou maior variação, tendo sido absorvido na proporção de $67 \%$, pelo cultivar Brasil 48 , e de 42,6\%, pelo cultivar Clause's Aurēlia. Os demais elementos tiveram sua absorção nesse período representando entre 48,5 e $66,7 \%$ do total. Para - cultivar Brasil 48 a variação foi menor, situando-se entre $59,5 \%$ (para cālcio) e $67 \%$ (para enxofre).

Nesse período de 21 dias que antecederam a colheita, a variação na acumulação proporcional foi menor para o cultivar clause's Aurēlia, situando-se entre $45,2 \%$ (para manganēs) e $59,1 \%$ (para cobre).Pa ra o cultivar Brasil 48 a acumulação de micronutrientes nesse período situou-se entre $49,7 \%$ (manganēs) e 69,2\% (zinco).

Do inĩcio aos 41 dias da cultura (terceira amostragem) a proporção de macronutrientes absorvida variou de 11 a 19,7\%, e a de micronutrientes, de 7,4 a 17\%. A variação no cultivar Brasil 48 foi mīnima nesse período, para os macronutrientes, tendo sido acumulados de 11 a $12,8 \%$ do total.

Os dados referentes à acumulação de nutrientes, em miligramas ou microgramas por planta, quilos ou gramas por hectare, e porcentagem, bem como as concentrações, encontram-se nas tabelas 3 a 13 . 


\subsubsection{Nitrogênio}

Os teores de nitrogénio encontrados na matéria seca das plantas, as quantidades do elemento acumuladas por planta e por hectare, bem como as respectivas porcentagens, encontram-se na tabela 3 .

Os teores na matéria seca variaram de 5,34 a 3,27\%, haven do um decréscimo na concentração desse elemento com a idade da planta. Esse fato está em concordância com a observação de outros autores, como ZINK e YAMAGUCHI (1962), na qual as concentrações variaram entre 6,65 e 3,10\%, FERNANDES et alii (1971) e LORENZ e MINGES (1942).

A acumulação de nitrogénio pelas plantas de alface foi lenta até os 30 dias, sendo intensificada a seguir e alcançando uma ta-xa diāria de $14,6 \mathrm{mg} / \mathrm{planta}$, entre o 510 e 0620 dia e mantendo-se praticamente a mesma atē o final da cultura, para o cultivar Brasil 48. A acumulação no cultivar Clause's Aurēlia alcançou uma taxa máxima entre o 410 e o 510 dias, e a seguir taxas decrescentes, até a colheita.

Atravēs da anālise de regressão obtiveram-se as equações para expressão matemática do crescimento (tabela 3 ). A equação de segundo grau representa satisfatoriamente a acumulação do nitrogénio pelo cultivar Brasil 48; para expressar o acúmulo de nitrogênio pelo cultivar Clause's Aurēlia a equação de terceiro grau è mais adequada, uma vez que a taxa de acumulação apresentou decréscimo no final da cultura.

Os cultivares apresentaram diferenças significativas na acumulação apenas por ocasião da colheita. Essa diferença foi devida aos diferentes teores de nitrogênio na matéria seca dos cultivares, 
Tabela 3. Teor de nitrogênio e quantidades absorvidas por cultura de alface, cultivares Brasil 48 (B.48) e Clause's Aurēlia (C.A.) em 6 épocas de amostragem. Média de 4 amostras. Populaçăo: $95000 \mathrm{plantas} / \mathrm{hectare}$

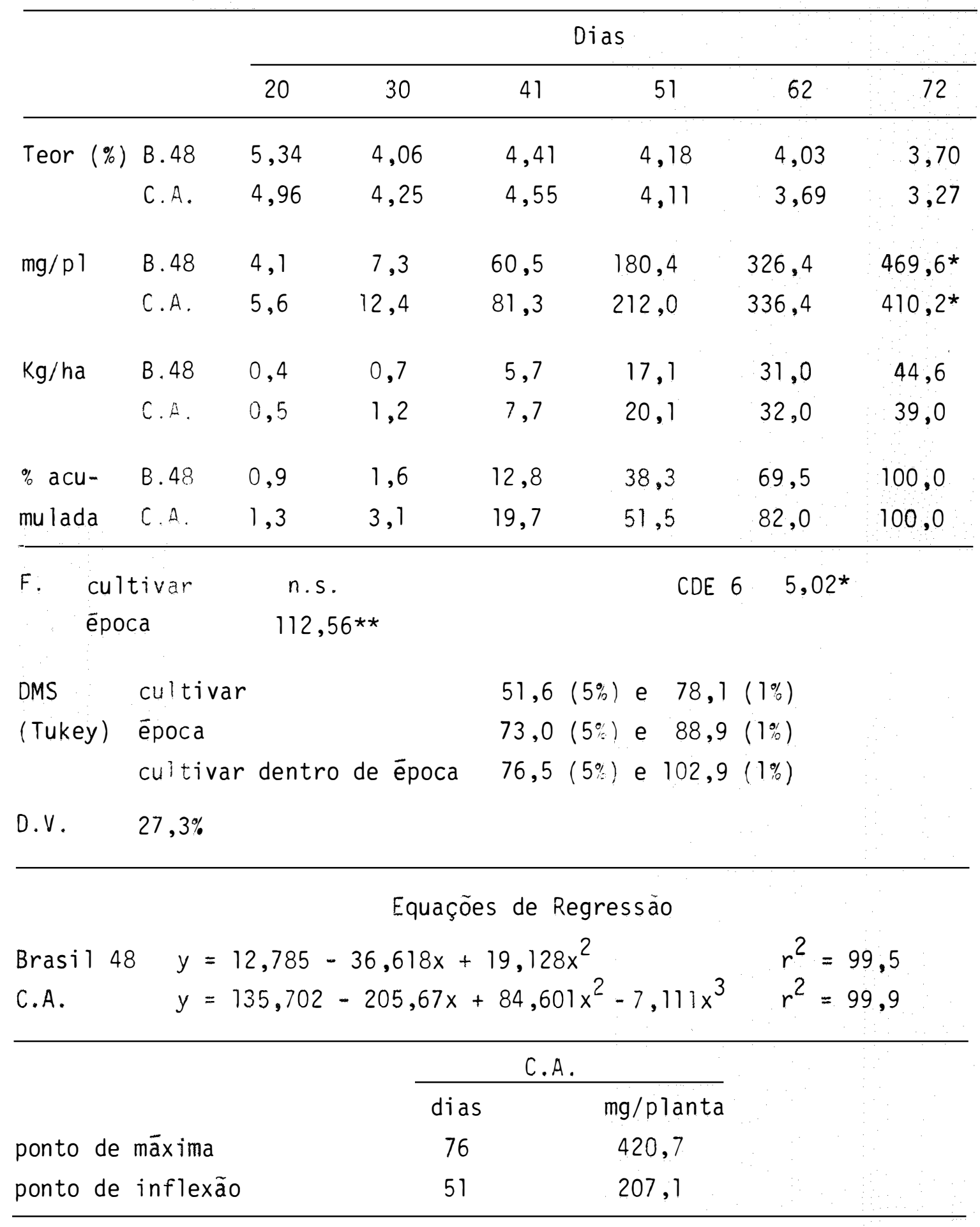


uma vez que a produção de matéria seca foi semelhante.

Foram exportados, atravēs da parte aérea das plantas, cer ca de $45 \mathrm{~kg} / \mathrm{ha}$ de nitrogénio, pelo cultivar Brasil 48, e de $39 \mathrm{Kg} / \mathrm{ha}$ pe10 cultivar Clause's Aurēlia. Esses resultados são superiores aos observados por FERNANDES et alii (1971), e inferiores aos obtidos no exterior pelos autores jâ citados. GARDNER e PEW (1979) referem-se tambēm a valores elevados, entre 100 e 110 quilos de nitrogènio acumulados por hectare até a colheita.

Observa-se que as maiores quantidades de nitrogēnio foram absorvidas nos estāgios finais da cultura, o que está em concordāncia com FERNANDES et alii (1971) e vem reforçar a recomendação emitida por estes a respeito da conveniência de se retardar a aplicação do nitrogênio em cobertura na cultura de alface.

\subsubsection{Fösforo}

A tabela 4 contém os dados relativos à absorção de fósforo pelas plantas e pela cultura de alface, em miligramas/planta, $\mathrm{kg} / \mathrm{ha}$ e porcentagem, bem como os teores desse elemento encontrados na matéria seca.

Os teores de fósforo situaram-se entre 0,67 e $0,92 \%$, ocor rendo maior variação no cultivar Brasil 48 que, a não ser na ūltima amos tragem, apresentou teores superiores aos do cultivar Clause.'s Aurēlia. Esses valores foram duas vezes mais elevados que os encontrados por FERNANDES et alii (1971) e LORENZ e MINGES (1942). Foram superiores aos 
de ZINK e YAMAGUCHI (1962) e de HAMILTON e BERNIER (1962) e, diferentemente do observado por PANDITA e ANDREW (1967), não ocorreu decréscimo no teor de fósforo das plantas com a aproximação da colheita.

Quanto às quantidades absorvidas, estiveram no final da cultura em torno de $100 \mathrm{mg}$ de fósforo por planta ou $9,5 \mathrm{~kg} / \mathrm{ha}$, não sendo encontrada diferença significativa entre os cultivares. Esse resultado é cerca de duas vezes o encontrado por FERNANDES et alii (1971), e a exportação de fósforo foi superior à relatada por LORENZ e MINGES (1942) e ZINK e YAMAGUCHI (1962), apesar da maior produção alcançada pelas culturas analisadas nesses trabalhos.

Em relação à absorção porcentual, observa-se que, de modo semelhante a outros nutrientes, a acumulação de fósforo se intensifica a partir dos trinta dias, alcançando taxa proporcionalmente superior $\bar{a}$ observada na produção de matéria seca.

A taxa máxima de acumulação, para os dois cultivares, ocorreu entre o 510 e 0620 dias, com um acréscimo diário de 3,2 a 3,3mg de fósforo por planta, o que equivale a $0,3 \mathrm{~kg} / \mathrm{ha}$ por dia. Após esse periodo, nos dez dias finais da cultura, a taxa diária decresceu a $2,8 \mathrm{mg}$ por planta.

Assim, ainda que para um ajustamento aos periodos iniciais de acumulação a equação de segundo grau com ponto de mĩnima seja satisfatōria para expressar a acumulação de fósforo pelas plantas de alface, para os estágios finais a de terceiro grau se revela mais adequada (tabela 4). 
Tabela 4. Teor de fósforo e quantidades absorvidas por plantas de alface, cultivares Brasil 48 (B.48) e Clause's Aurélia (C.A.), em 6 épocas de amostragem. Populaçăo: 95000 plantas/hectare

\begin{tabular}{|c|c|c|c|c|c|c|c|}
\hline & \multicolumn{6}{|c|}{ Dias } \\
\hline & & 20 & 30 & 41 & 51 & 62 & 72 \\
\hline \multirow[t]{2}{*}{ Teor (\%) } & B. 48 & 0,67 & 0,81 & 0,81 & 0,87 & 0,92 & 0,78 \\
\hline & C.A. & 0,76 & 0,64 & 0,78 & 0,69 & 0,80 & 0,80 \\
\hline \multirow[t]{2}{*}{$\mathrm{mg} / \mathrm{pl}$. } & B. 48 & 0,52 & 1.45 & 11,09 & 37,20 & 71,90 & 99,98 \\
\hline & C.A. & 0,85 & 1,86 & 13,81 & 35,23 & 72,06 & 100,13 \\
\hline \multirow[t]{2}{*}{$\mathrm{Kg} / \mathrm{ha}$} & B. 48 & 0,05 & 0,14 & 1,05 & 3,53 & 6,83 & 9,50 \\
\hline & C.A. & 0,08 & 0,18 & 1,31 & 3,35 & 6,85 & 9,51 \\
\hline$\%$ acumu & B. 48 & 0,5 & 1,5 & 11,0 & 37,1 & 71,9 & 100,0 \\
\hline lada & C.A. & 0,8 & 1,9 & 13,8 & 35,2 & 72,0 & 100,0 \\
\hline \multicolumn{2}{|c|}{$\begin{array}{c}\text { F. cultivar } \\
\text { época }\end{array}$} & & $200,03 * *$ & & \multicolumn{3}{|c|}{ CDE 6 - n.s. } \\
\hline DMS & \multicolumn{3}{|l|}{ cultivar } & \multicolumn{3}{|c|}{$8,39(5 \%)$ e $12,70(1 \%)$} & \\
\hline \multirow[t]{2}{*}{ (Tukey) } & \multicolumn{3}{|l|}{ época } & 12,44 & \multicolumn{2}{|c|}{$(5 \%)$ e $15,16(1 \%)$} & \\
\hline & \multicolumn{3}{|c|}{ cultivar dentro de época } & 12,84 & \multicolumn{2}{|c|}{$(5 \%)$ e $17,26(1 \%)$} & \\
\hline C.V. & $22,0 \%$ & & & & & & \\
\hline
\end{tabular}

Equações de Regressáo

\begin{tabular}{|c|c|c|c|c|c|}
\hline $\begin{array}{l}\text { B. } 48 \\
\text { C.A. }\end{array}$ & $\begin{array}{l}y=26,256 \\
y=22,445\end{array}$ & $\begin{array}{r}-37,91 \\
-\quad 32,22\end{array}$ & $\begin{array}{l}13,954 x^{2} \\
12,037 x^{2}\end{array}$ & $\begin{array}{l}-0,928 x^{3} \\
-0,747 x^{3}\end{array}$ & $\begin{array}{l}\left(r^{2}=99,77\right) \\
\left(r^{2}=99,71\right)\end{array}$ \\
\hline & & \multicolumn{2}{|c|}{ B. 48} & \multicolumn{2}{|c|}{ C.A. } \\
\hline & & dias & $\mathrm{mg} / \mathrm{pl}$. & dias & $\mathrm{mg} / \mathrm{pl}$. \\
\hline ponto & de mäxima & 96 & 142,6 & 104 & 163,1 \\
\hline ponto & inflexão & 62 & 70,1 & 65 & 80,9 \\
\hline
\end{tabular}




\subsubsection{Potāssio}

A acumulação de potássio pelas plantas e pela cultura de alface apresentou diferenças significativas entre os cultivares estudados neste trabalho, por ocasião da quinta e da sexta amostragem (aos 62 e aos 72 dias da cultura). Essas diferenças foram devidas às ocorridas no teor de potássio encontrado nas plantas.

0 teor de potássio na matēria seca da parte aérea das plantas variou sem uma tendência definida, entre 7,31 e $8,45 \%$, para 0 cultivar Brasil 48, e entre 4,97 e 7,50, no cultivar Clause's Aurēlia. Esses valores foram superiores aos obtidos por FERNANDES et alii (1971) e mais prōximos dos de ZINK e YAMAGUCHI (1962).

A quantidade de potássio acumulada tambēm foi superior à observada por FERNANDES et alii (1971). A acumulação por hectare $(96,6$ e $72,1 \mathrm{~kg}$ ) esteve mais próxima dos resultados obtidos no exterior por LO RENZ e MINGES (1942) e pelos abrangidos por ZINK e YAMAGUCHI (1971), ape sar da grande diferença de produção observada entre esses trabalhos e os realizados no Brasil.

A tendência geral da acumulação seguiu o padrão observado para nitrogênio e fósforo, com aceleração a partir do trigésimo dia, sen do que no caso do potássio as taxas de acumulação foram crescentes atē a colheita, o que torna adequadas para expressar a absorção desse elemento as equações de segundo grau, obtidas atravēs da anālise de regressão (tabela 5). 
Tabela 5. Teor de potássio e quantidades absorvidas por plantas de alface, cultivares Brasil 48 (B.48) e Clause sAurélia (C.A.), en 6 épocas de amostragem. Populaçào: 95000 plantas/hectare

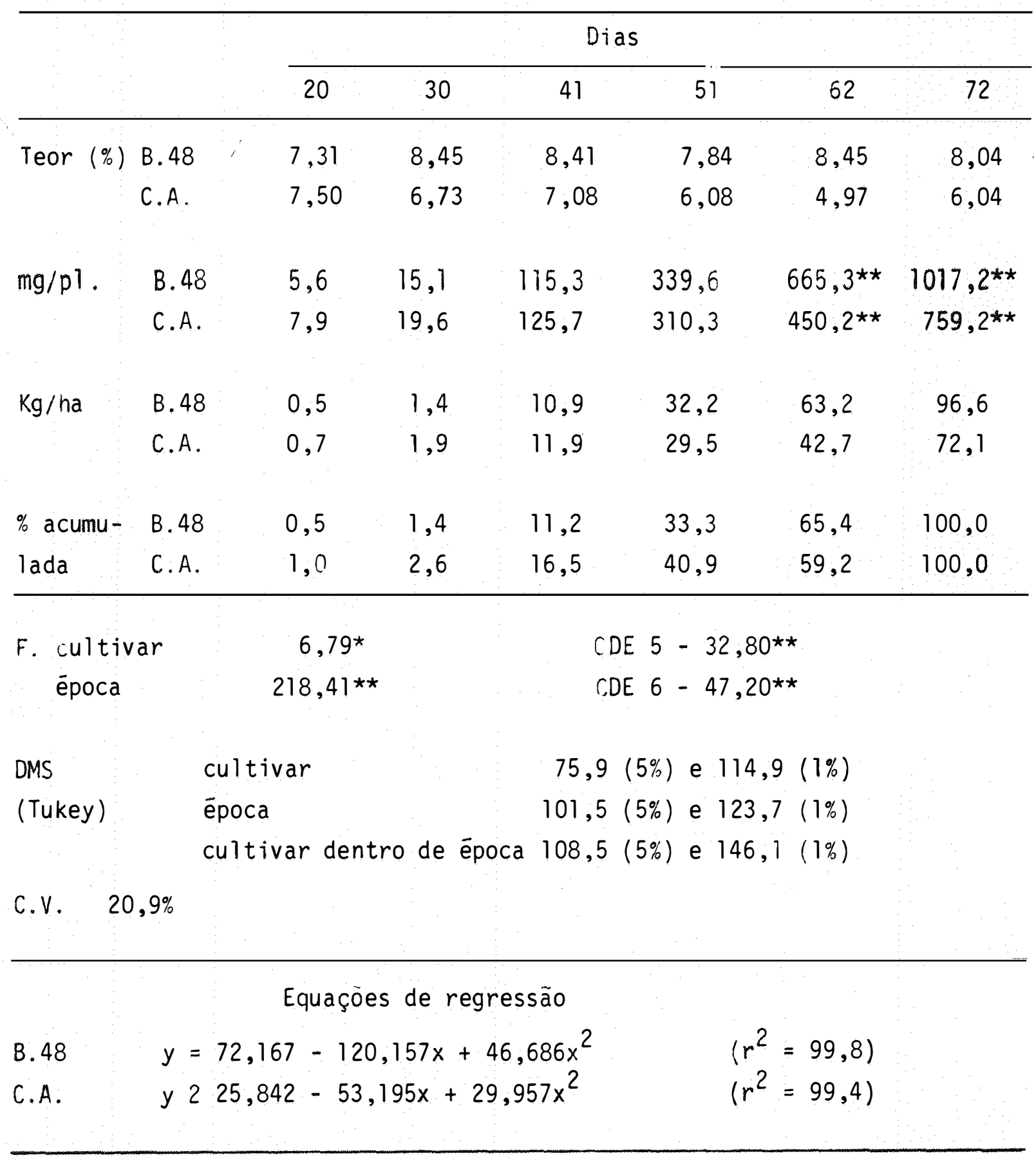




\subsubsection{Cālcio}

Os teores de cálcio na matéria seca variaram entre 1,05 e 1,65\%, sendo próximos aos obtidos por FERNANDES et alii (1971), LORENZ e MINGES (1942) e ZINK e YAMAGUCHI (1962).

Os cultivares estudados apresentaram diferenças significativas na absorção de potássio aos 62 e aos 72 dias, tendo o cultivar Clause's Aurêlia acumulado, atê a colheita $199,8 \mathrm{mg}$ de cálcio por planta $(15,3 \mathrm{~kg} / \mathrm{ha})$, e o cultivar Brasil 48, 161,2 mg $(15,3 \mathrm{~kg} / \mathrm{ha})$. Esses valores são superiores aos obtidos por FERNANDES et alii, e inferiores aos determinados em trabalhos realizados no exterior, representando cerca de metade da quantidade de potássio acumulada, por hectare, em culturas estudadas por ZINK e YAMAGUCHI (1962).

A acumulação de cálcio na cultura de alface acompanhou a tendência observada em outros nutrientes, de aceleração a partir dos trinta dias, apresentando taxas crescentes até a colheita. As taxas de acumulação diāria máxima observadas foram de $6,48 \mathrm{mg}$ por planta, no cultivar Clause's Aurélia, e 4,92 mg por planta para o cultivar Brasil 48, ambas no periodo dos 62 aos 72 dias.

As equações obtidas através da anālise de regressão dos dados de acumulação de cálcio encontram-se na tabela 6 . 
Tabela 6. Teor de cälcio e quantidades absorvidas por plantas de alface, cultivares Brasil 48 (B.48) e Clause's Aurēlia (C.A.), em 6 épocas de amostragem. População: $95000 \mathrm{plantas} / \mathrm{hectare}$

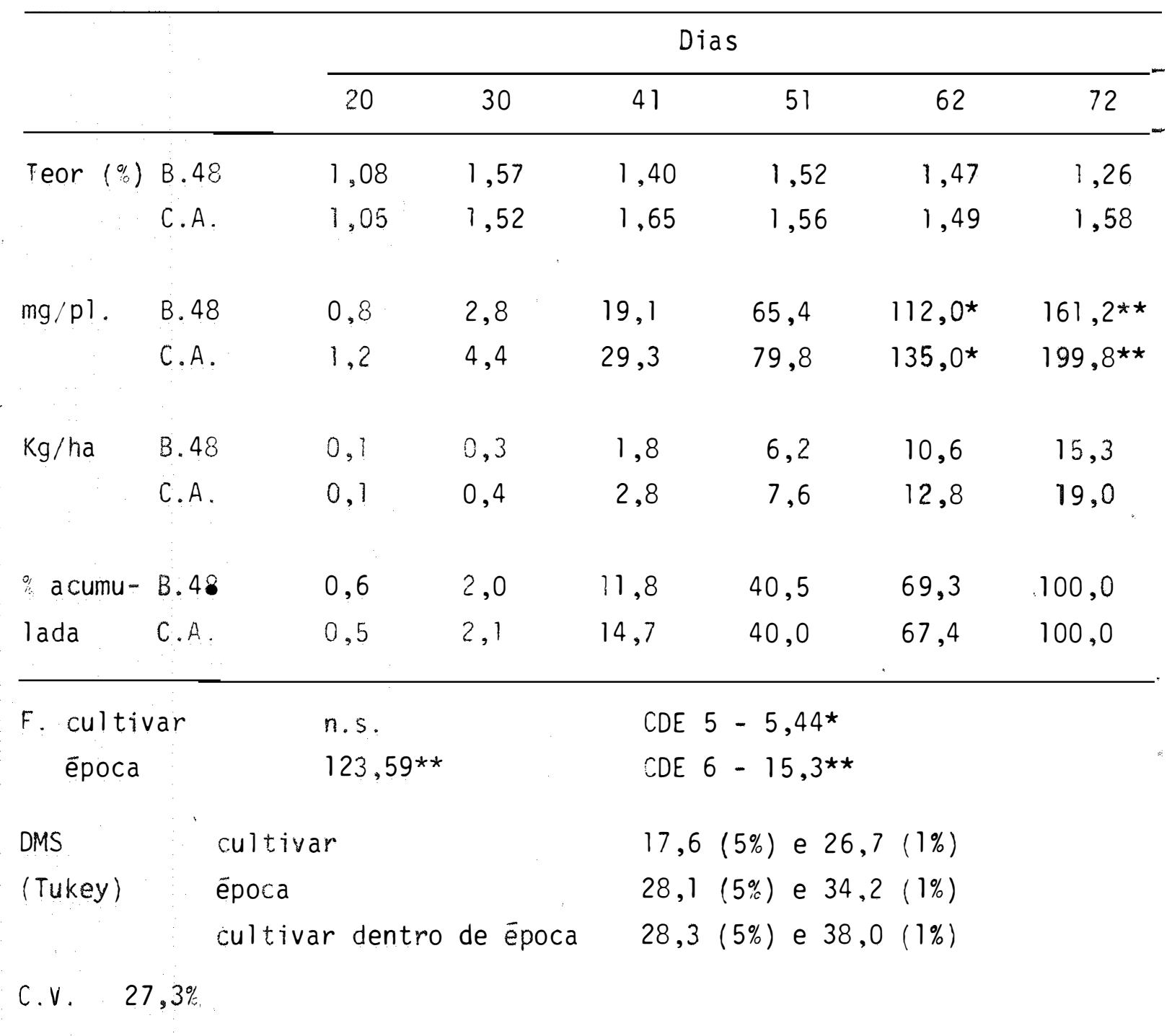

Equaçoes de regressão
CV B. 48
$y=2,192-11,051 x+6,379 x^{2}$
CV C.A.
$y=2,881$
$-12,608 x+7,659 x^{2}$
$\left(r^{2}=99,3\right)$
$\left(r^{2}=99,7\right)$ 


\subsubsection{Magnësio}

A acumulaçao de magnésio mostrou diferenças significativas entre os cultivares, nas amostragens realizadas aos 51, 62 e 72 dias da cultura, tendo o cultivar Clause's Aurēlia acumulado maior quantidade, em todas as ëpocas, e apresentado maior precocidade na acumulação proporcional (tabela 7).

Não obstante as diferenças observadas, a acumulação seguiu a tendéncia geral da absorção de nutrientes, com aceleração a partir dos trinta dias.

O cultivar Brasil 48 apresentou taxas de acumulação crescentes até a colheita, alcançando $1,68 \mathrm{mg}$ por planta e por dia, e o cultivar Clause's Aurëlia apresentou uma taxa diāria máxima de 1,53 mg por planta entre o 410 e o 510 dia da cultura, e taxas decrescentes apōs, o que torna mais adequada para expressar matematicamente seu crescimento a equação de terceiro grau.

Os teores de magnésio encontrados na matéria seca variaram de 0,37 a 0,46\%, apresentando o cultivar Brasil 48, a partir dos 41 dias, teores mais elevados. Esses valores foram pouco superiores aos obtidos por FERNANDES et alie (1971), situando-se dentro da faixa abrangida pelos dados de ZINK e YAMAGUCHI (1962) e outros autores.

As quantidades acumuladas foram superiores às relatadas por FERNANDES et akii (1971) e bastante inferiores às de ZINK e YAMAGUCHI (1962). 
Tabela 7. Teor de magnésio e quantidades absorvidas por plantas de alface, cultivares Brasil 48 (B.48) e Clause'sAurēlia (C.A.), em 6 épocas de amostragem. População: 95000 plantas/hectare

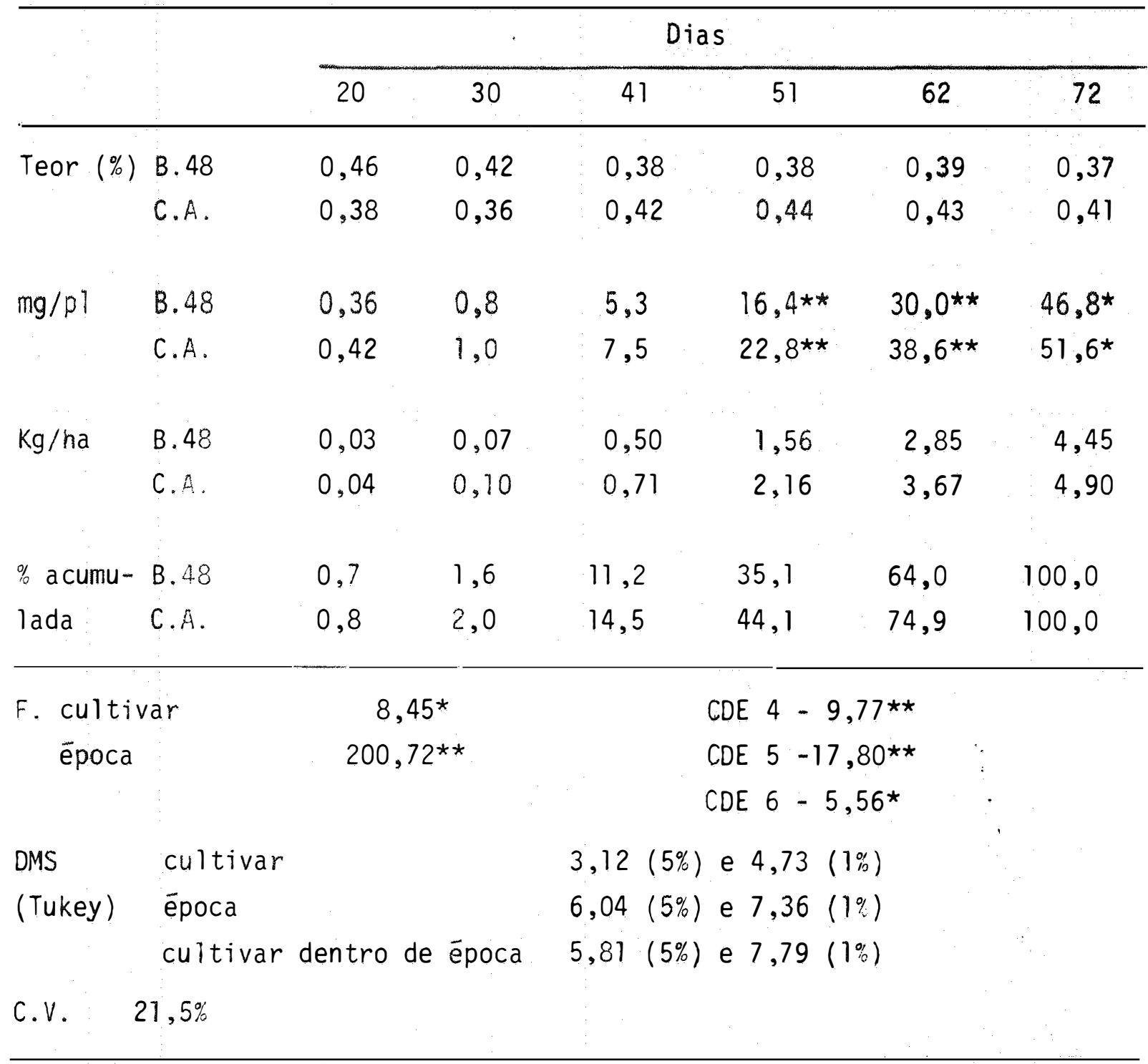

Equações de regressão

cv. B. $48 \quad y=3,187-5,312 x+2,111 x^{2} \quad\left(r^{2}=99,86\right)$

cv. C.A. $\quad y=14,351-21,384 x+8,377 x^{2}-0,629 x^{3}\left(r^{2}=99,89\right)$

\begin{tabular}{lcc}
\hline & \multicolumn{2}{c}{ C.A. } \\
\cline { 2 - 3 } & Dias & $\mathrm{mg} / \mathrm{pl}$ \\
ponto de máxima & 85 & 60,0 \\
ponto de inflexão & 55 & 29,5 \\
\hline
\end{tabular}




\subsubsection{Enxofre}

Em relação à acumulação de enxofre, foram encontradas diferenças significativas entre os. cultivares apenas aos 51 dias (quarta amostragem).

Para o cultivar Brasil 48 a taxa māxima de absorção foi de $1 \mathrm{mg}$ por planta por dia, e ocorreu entre o 510 e 0620 dia, havendo um decréscimo no perīodo seguinte. Para o cultivar clause's Aurēlia, a taxa mäxima ocorreu entre o 410 e o 510 dia, sendo de 0,87 mg por planta por dia.

As quantidades totais acumuladas por planta, ao redor de $21 \mathrm{mg}$, e de $2 \mathrm{~kg} / \mathrm{ha}$ representam 65 a $67 \%$ do total observado por FERNANDES et alie (1971), como consequéncia dos menores teores encontrados nas plantas no presente trabalho.

A acumulaçào do enxofre, para o cultivar Brasil 48, se re velou mais precoce que a dos demais nutrientes, com $85 \%$ da quantidade total acumulados atē o 620 dia. Em relação à quarta amostragem, observa-se que $57 \%$ do total de enxofre foi acumulado pelo cultivar Clause's Aurēlia até essa época, enquanto para os demais elementos a acumulação situou-se entre 41 e $51 \%$.

Os dados relativos à absorção de enxofre encontram-se na tabela 8. 
Tabela 8. Teor de enxofre e quantidades absorvidas por plantas de alface, cultivares Brasil 48.(B.48) e Clause'sAurēlia (C.A.), em 6 ēpocas de amostragem. População: 95000 plantas/hectare

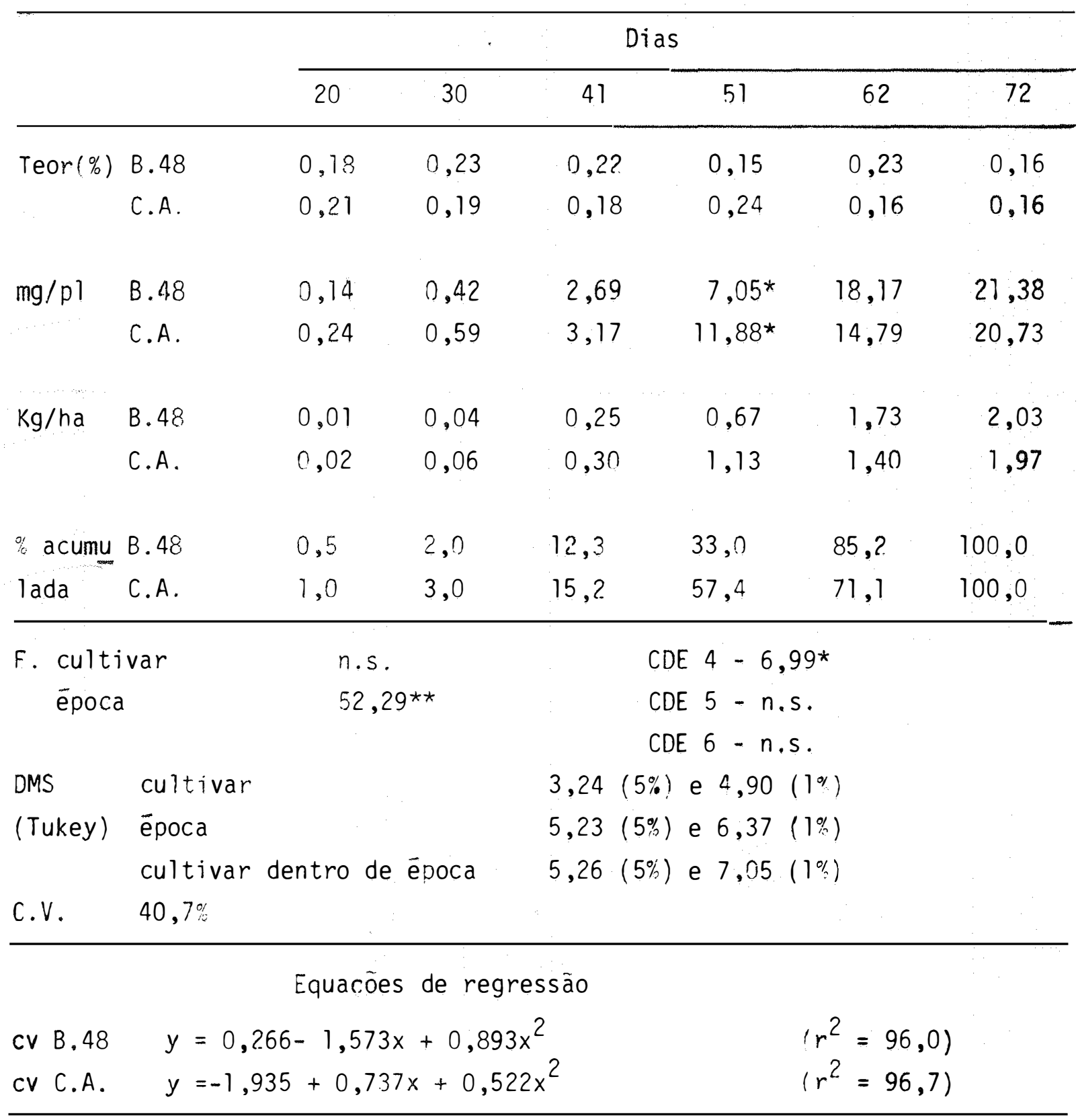




\subsubsection{Boro}

0 teor de boro encontrado nas plantas variou de $59 \quad \begin{aligned} & 59 \\ & \text { a }\end{aligned}$ $93 \mathrm{ppm}$, sendo bastante superior aos teores encontrados por HAMILTON e BERNIER (1955), MIDGLEY e DUNKLEE (1946), BEAR (1949) e situando-se na faixa considerada como töxica por ROORDA VAN EYSINGA et alii (1971).

Em relação à quantidade total acumulada, foi superior à observada por HAMILTON e BERNIER (1955), como consequëncia dos teores mais elevados ericontrados neste trabalho.

Para os dois cultivares, a taxa de acumulação foi crescente até os 510̣ dia, diminuiu acentuadamente entre o 510 e o 620 dia, atingindo os valores máximos (36 e 39 ug por planta por dia) nos dez dias que antecederam a colheita. A acumulação de boro nesse período foi proporcionalmente superior à observada para outros nutrientes, com cerca de $40 \%$ do total absorvido nessa ëpoca.

Não foram encontradas diferenças significativas entre os cultivares em relação à acumulação de boro, e os dados a ela referentes encontram-se na tabela 9.

\subsubsection{Cobre}

Os teores de cobre encontrados nas plantas de alface variaram entre 9 e 18 ppm, sendo, a partir da quarta amostragem, superiores no cultivar Brasil 48. Esses teores são superiores aos obtidos por 
Tabela 9. Teor de boro e quantidades absorvidas por plantas de alface, cultivares Brasil 48. (B.48) e Clause's Aurēlia (C.A.), em 6 ēpocas de amostragem. População: 95000 plantas/hectare

\begin{tabular}{|c|c|c|c|c|c|c|c|}
\hline & & \multicolumn{5}{|c|}{ Dias } & \multirow[b]{2}{*}{72} \\
\hline & & 20 & 30 & 41 & 51 & 62 & \\
\hline \multirow[t]{2}{*}{ ppm } & & 59 & 89 & 60 & 93 & 68 & 70 \\
\hline & & 62 & 67 & 67 & 82 & 62 & 76 \\
\hline \multirow[t]{2}{*}{$\mu g / p 1$} & .48 & 4,6 & 16,0 & 82,7 & 402,3 & 537,1 & 896,4 \\
\hline & . A. & 7,0 & 19,3 & 119,7 & 423,0 & 569,5 & 958,0 \\
\hline \multirow[t]{2}{*}{$\mathrm{g} / \mathrm{ha}$} & .48 & 0,4 & 1,5 & 7,9 & 38,2 & 51,0 & 85,2 \\
\hline & . A. & 0,7 & 1,8 & 11,4 & 40,2 & 54,1 & 91,0 \\
\hline$\%$ acumu & 3.48 & 0,5 & 1,8 & 9,3 & 44,8 & 59,8 & 100,0 \\
\hline Tada & C.A. & 0,8 & 2,0 & 12,5 & 44,2 & 59,4 & 100,0 \\
\hline \multicolumn{2}{|c|}{ F. cultivar } & \multicolumn{2}{|c|}{ n.s. } & \multicolumn{4}{|c|}{ CDE - n.s. } \\
\hline DMS & cultivar & & & 63,6 & e 96, & $(1 \%)$ & \\
\hline \multirow[t]{2}{*}{ (Tukey) } & ēpoca & & & 161,6 & e 196, & $(1 \%)$ & \\
\hline & cultivar & dentro & ёроса & 149,0 & e 199, & $(1 \%)$ & \\
\hline C.V. & $31,6 \%$ & & & & & & \\
\hline
\end{tabular}

Equações de regressão
B. 48
$y=24,325-70,290 x+35,927 x^{2}$
$\left(r^{2}=98,2\right)$
C.A.
$y=22,744-66,459 x+36,876 x^{2}$
$\left(r^{2}=98,7\right)$ 
HAMILTON e BERNIER (1955) e HARWARD et alie (1955), aproximando-se da faixa considerada normal por ROORDA VAN EYSINGA et alii (1971).

As quantidades totais acumuladas (16 a $18,7 \mathrm{~g} / \mathrm{ha}$ ) representaram 60 a 70\% da determinada por HAMILTON e BERNIER (1955), somando-se os resultados obtidos por este autor para a produção económica e os resíduos da parte aērea, o que resulta em produção superior à obtida neste trabalho.

0 padrão de acumulação de cobre foi semelhante ao observado para os domeis nutrientes, acompanhando proporcionalmente a produção de matēria seca. As taxas de acumulação foram crescentes atē a colheita, o que tornou possível o uso das equações de segundo grau para expressar a acumulação (tabela 10).

Os cultivares Brasil 48 e Clause's Aurēlia apresentaram diferença significativa na acumulação de cobre por ocasião da colheita. Essa diferença foi devida aos diferentes teores encontrados nas plantas, uma vez que a produção de matéria seca foi semelhante.

\subsubsection{Ferro}

$\mathrm{Na}$ acumulação de ferro os cultivares Brasil 48 e Clause's Aurēlia apresentaram diferença significativa por ocasião da colheita, diferença essa devida aos teores do elemento encontrados nas plantas.

A marcha da absorção foi diferente para os dois cultivares, pois o cultivar Brasil 48 apresentou taxas crescentes atē a colheita, 
Tabela 10. Teor de cobre e quantidades absorvidas por plantas de alface, cultivares Brasil 48 (B.48) e Clause's Aurēlia (C.A.), em 6 épocas de amostragem. População: 95000 plantas/hectare

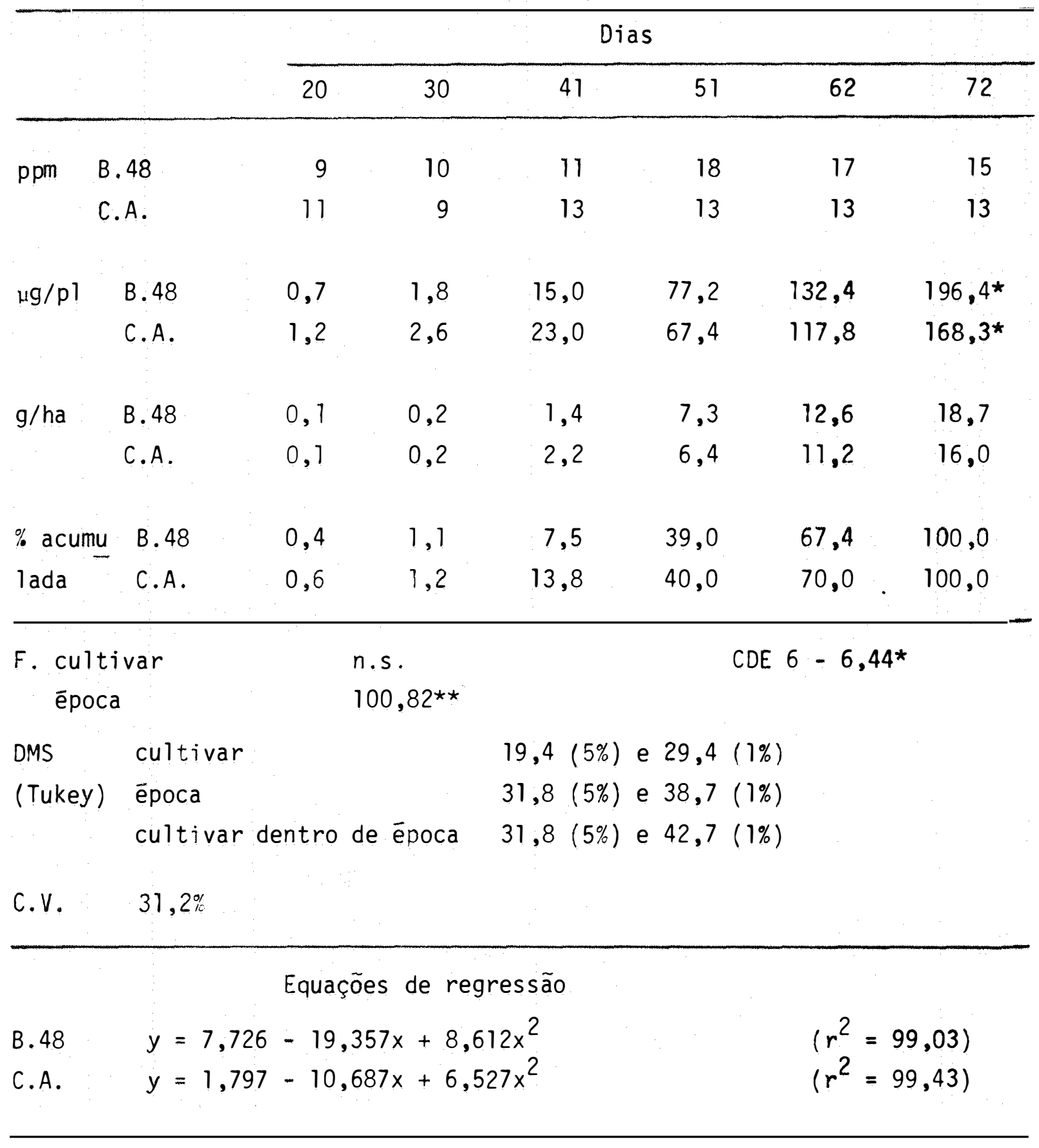


enquanto o cultivar Clause's Aurēlia apresentou uma taxa māxima entre o 410 e o 510 dia, e taxas decrescentes após esse período. Isso resultou que, enquanto $40 \%$ do total do ferro acumulado pelo cultivar Brasil 48 o foi nos ūltimos dez dias da cultura, nesse mesmo período o cultivar Clau se's Aurélia acumulou apenas $12 \%$ do total, sendo esse o caso de acumulação mais precoce encontrado no presente trabalho.

As equações obtidas atravēs da anālise de regressao constam da tabela 11 e refletem as diferenças encontradas na acumulação do ferro.

Os teores encontrados nas plantas superaram os relatados por HARWARD et alii (1955), mesmo quando comparados aos obtidos por esse autor em plantas cultivadas em meio com nỉveis elevados de ferro, e superaram tambëm os observados por SANCHEZ CONDE (1980) e SANCHEZ CONDE e AZUARA (1980), estando na faixa considerada como pertencente a plan tas sadias por ROORDA VAN EYSINGA et alii (1971) e próximos ou ultrapassando o limite superior observado por BEAR et alii (1949) nos EUA.

Em relação a quantidade total acumulada, não foram encontrados dados para comparação.

\subsubsection{Manganès}

Foi em relação ao manganès que os cultivares Brasil 48 e Clause's Aurēlia apresentaram diferença mais expressiva na acumulação. Como se pode observar nos dados contidos na tabela 12, os teores de manganês encontrados na matéria seca foram, a partir da segunda amostragem 
Tabela 11. Teor de ferro e quantidades absorvidas por plantas de alface, cultivares Brasil 48 (B.48) e Clause's Aurēlia (C.A.), em 6 ēpocas de amostragem. População: 95000 plantas/hectare

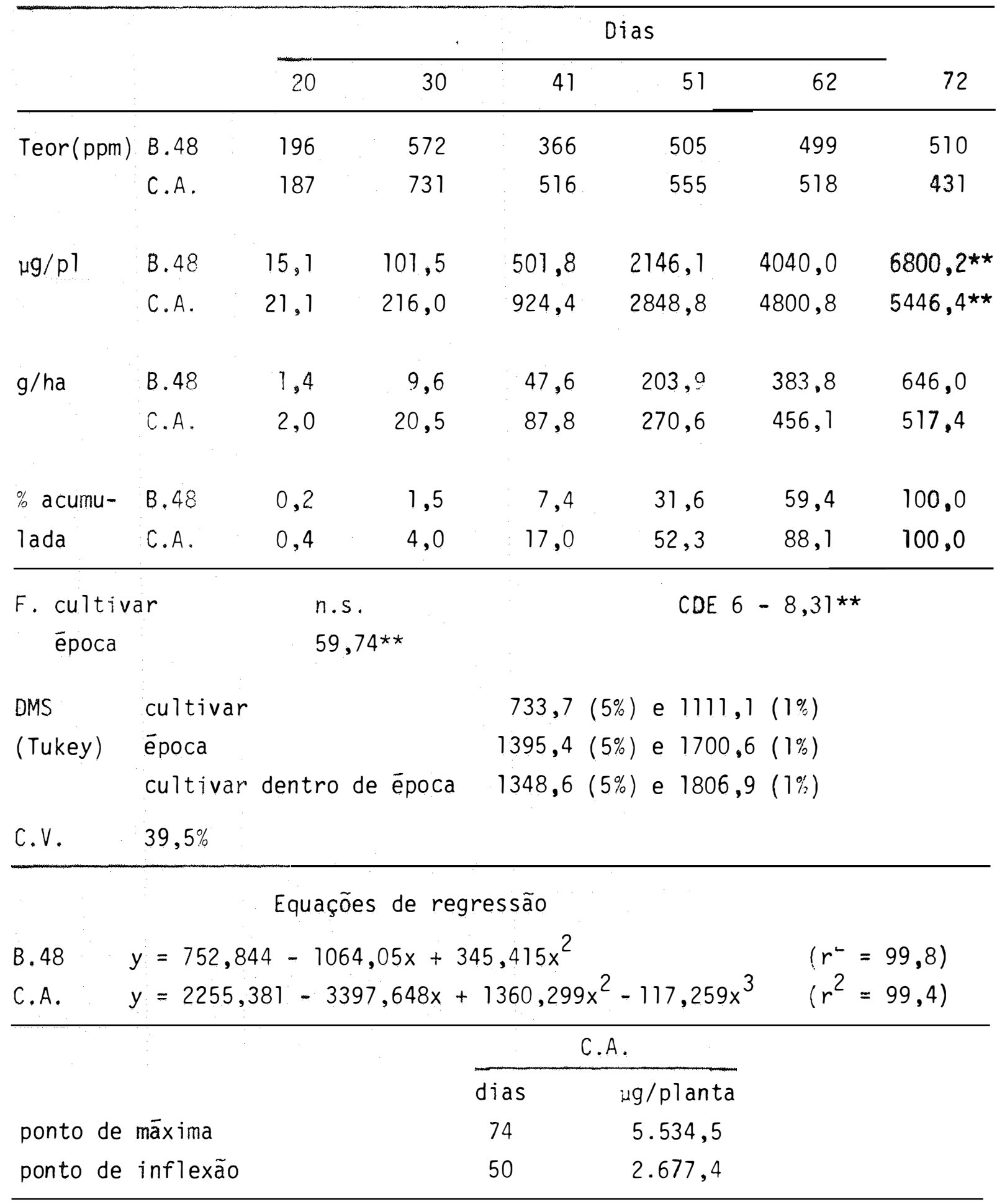


(300 dia), de trēs a cinco vezes superiores no cultivar Brasil 48, o que resultou em diferenças significativas na acumulação aos 51, 62 e 72 dias da cultura (tabela 12).

O cultivar Brasil 48 apresentou uma taxa māxima de acumula ção entre o 410 e o 510 dia (132 $\mu$ g por planta por dia) e, depois dessa época, taxas decrescentes. ( 0 cultivar Clause's Aurēlia apresentou taxas de absorção crescentes até 0510 dia, dessa data ao 620 dia um estacionamento na acumulação e, do 620 dia à colheita uma acumulação intensa na maior taxa observada para esse elemento nesse cultivar $(47,4 \mu \mathrm{g}$ por planta por dia).

Os teores de manganēs encontrados no cultivar Clause's Aurêlia foram semelhantes aos observados por BEAR et alii (1946), HAMILTON e BERNIER (1955), SANCHEZ CONDE (1980) e SANCHEZ CONDE e AZUARA (1980) e estiveram situados na faixa considerada como pertencente a plantas sadias por ROORDA VAN EYSINGA (1971), e nos limites determinados por HARWARD et alii (1955) para plantas cultivadas em meio nutritivo normal. Já os teores encontrados no cultivar Brasil 48 estiveram muito acima dos observados por esses autores, estando próximos, mas ainda acima dos observados por HARWARD et alii (1955) em plantas cultivadas em meio com elevado teor de ferro e aluminio. Os teores observados no cultivar Brasil 48 só foram inferiores aos encontrados por este ültimo autor em plantas de alface cultivadas em meio com elevado teor de manganès (a nỉveis tōxicos).

Considerando que o teor de ferro encontrado nas plantas foi elevado, em relação aos encontrados na literatura, e que o solo em que foi conduzida a cultura costuma apresentar elevados teores de ferro 
Tabela 12. Teor de manganès e quantidades absorvidas por plantas de alface, cultivares Brasil 48 (B.48) e Clause's Aurēlia (C.A.). em 6 épocas de amostragem. População: 95000 plantas/hectare

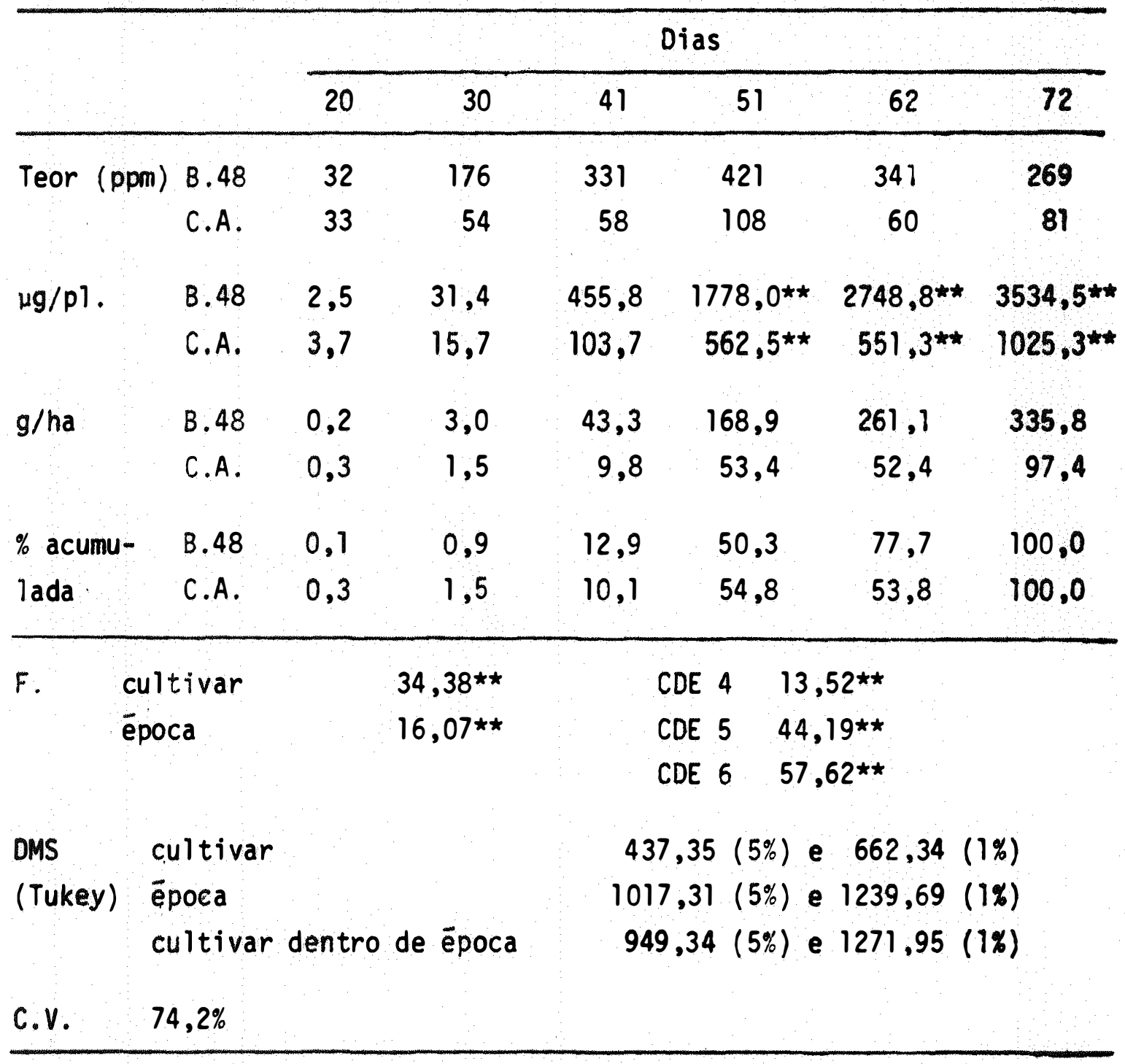

Equaçõès de Regressão

B. $48 y=1.258,168-1.922,589 x+753,046 x^{2}-61,566 x^{3}\left(r^{2}=99,6\right)$ C.A. $y=-21,410-34,217 x+34,169 x^{2} \quad\left(r^{2}=93,9\right)$

\begin{tabular}{lcc}
\hline & \multicolumn{2}{c}{$B .48$} \\
\cline { 2 - 3 } & dias & $\mu \mathrm{g} / \mathrm{p} 1$. \\
ponto de māxima & 78 & $3.672,1$ \\
ponto de inflexão & 52 & $1.764,8$ \\
\hline
\end{tabular}


disponíveis às plantas, parece repetir-se neste ensaio o observado por HARWARD et alii (1955), em que o elevado teor de ferro no meio causou elevação no teor de manganẽs das plantas de alface.

\subsubsection{Zinco}

De modo semelhante ao observado para enxofre e boro, nos dois cultivares, e para manganēs, no cultivar clause's Aurëlia, a acumulação de zinco estacionou, neste cultivar, ou diminuiu acentuadamente (no cultivar Brasil 48), no período entre o 510 e o 620 dia da cultura, com retomada posterior da acumulação a taxas elevadas, como se pode cons tatar através dos dados da tabela 13.

A acumulação de zinco diferiu das dos demais nutrientes, sendo bastante tardia, com cerca de 64\% (cultivar Brasil 48) e 52\% (cultivar clause's Aurélia) do total absorvidos nos ültimos dez dias da cultura.

As quantidades acumuladas foram diferentes para os dois cultivares, tendo o cultivar Brasil 48 acumulado mais do dobro da quanti dade acumulada pelo cultivar clause's Aurélia, refletindo as diferenças encontradas no teor de zinco das plantas.

A acumulação pelo cultivar Clause's Aurélia foi semelhante à observada por HAMILTON e BERNIER (1955) e a calculada para o Brasil 48 foi cerca do dobro.

Os teores encontrados nos dois cultivares foram superiores aos observados por HAMILTON e BERNIER (1955), os do cultivar 
Tabela 13. Teor de zinco e quantidades absorvidas por plantas de alface. cultivares Brasị 48 (B.48) e Clause'sAurēlia (C.A.), em 6 épocas de amostragem. População: 95000 plantas/hectare

\begin{tabular}{|c|c|c|c|c|c|c|c|}
\hline & & \multicolumn{6}{|c|}{ Dias } \\
\hline & & 20 & 30 & 41 & 51 & 62 & 72 \\
\hline \multirow[t]{2}{*}{ Teor (ppm) } & B. 48 & 79 & 195 & 359 & 317 & 202 & 354 \\
\hline & C.A. & 48 & 87 & 205 & 192 & 112 & 166 \\
\hline \multirow[t]{2}{*}{$\mu \mathrm{g} / \mathrm{pl}$} & B. 48 & 7,8 & 34,8 & 455,7 & 1376,9 & $1583,0 *$ & $4462,0 * *$ \\
\hline & $C . A$. & 5,4 & 25,2 & 342,7 & 1021,1 & $1018,6 *$ & $2125,3 * *$ \\
\hline \multirow[t]{2}{*}{$\mathrm{g} / \mathrm{ha}$} & B. 48 & 0,7 & 3,3 & 43,3 & 130,8 & 150,4 & 423,9 \\
\hline & C.A. & 0,5 & 2,4 & 32,6 & 97.0 & 96,8 & 201,9 \\
\hline$\%$ acumu- & B. 48 & 0,2 & 0,8 & $10, ?$ & 30,8 & 35,5 & 100,0 \\
\hline lada & $C . A$. & 0,2 & 1,2 & 16,1 & 48,0 & 47,9 & 100,0 \\
\hline \multirow{2}{*}{\multicolumn{2}{|c|}{$\begin{array}{l}F \text {. cultivar } \\
\text { ëpoca }\end{array}$}} & \multicolumn{2}{|c|}{$37,63 * \star$} & \multicolumn{4}{|c|}{$\operatorname{CDE} 5-6,67^{*}$} \\
\hline & & \multicolumn{2}{|c|}{$58,72 * *$} & \multicolumn{4}{|c|}{$\operatorname{CDE} 6-114,30 * *$} \\
\hline DMS & cultivar & & & 224,81 & ) e 340 & $5(1 \%)$ & \\
\hline \multirow[t]{2}{*}{ (Tukey) } & época & & & 695,11 & 6) e 847 , & $(1 \%)$ & \\
\hline & cultivar & dentro & época & 629,01 & ) e 844 , & $8(1 \%)$ & \\
\hline C.V. & $44,0 \%$ & & & & & & \\
\hline
\end{tabular}

Equações de regressão
B. 48
$y=769,75-879,726 x+239,295 x^{2}$
$\left(r^{2}=93,9\right)$
C.A.
$y=23,039-111,967 x+74,192 x^{2}$
$\left(r^{2}=94,7\right)$ 
Clause's Aurēlia estiveram na faixa observada por SANCHEZ CONDE (1980) e os do Brasil 48 foram superiores. Os teores de ambos situaram-se na faj xa considerada como pertencente a plantas normais por ROORDA VAN EYSINGA et alii (1971).

\subsection{Ensaio em casa de vegetação}

\subsubsection{Sintomatologia das deficiēncias}

Os sintomas foram, na maioria dos casos, semelhantes para os dois cultivares e são descritos de maneira geral, destacando-se apenas os casos em que houveram diferenças. As datas de aparecimento de sintomas referem-se principalmente ao cultivar Brasil 48.

\subsubsection{Tratamento completo}

As plantas submetidas a tratamento com solução nutritiva completa desenvolveram-se mais que as submetidas a tratamentos com omissão de nutrientes, com excessão daquelas submetidas a omissão de enxofre.

Apresentaram coloração verde intensa $\left(L-6^{0}-9\right) *$ nas folhas velhas e verde ligeiramente mais clara nas folhas mais novas $\left(L-8^{\circ}-10\right.$

\footnotetext{
* VILlalobos-domingues e VILlalobos, 1947. Atlas de los colores. Ed. El Ateneo-Buenos Aires.

0 sistema de classificação e de anotação ē o seguinte:

a) a letra ou letras indicam a cor e seu matiz;

b) o número ou números dão o valor de luminosidade;

c) o grau expressa a tonalidade do matiz.
} 
no cultivar Brasil 48 e L-10 -10 no Clause's Aurēlia).

0 sistema radicular apresentou coloração branca acinzentada e aspecto sadio.

\subsubsection{Tratamento com omissão de nitrogēnio}

Nove dias após o início dos tratamentos foram observados menor desenvolvimento e ligeira diferença na coloração. Em torno do décimo sexto dia as diferenças mostraram-se acentuadas, apresentando-se a coloração geral das plantas verde mais clara $\left(L-8^{0}-11\right.$ a $\left.L-6^{0}-13\right)$ e as folhas mais velhas acentuadamente pālidas $\left(Y L-6^{0}-17\right)$. 0 desenvolvimento estacionou e ocorreu intensa queda de folhas.

As plantas deficientes em nitrogênio não apresentaram murchamento nas horas quentes do dia, como aconteceu com as submetidas a outros tratamentos, sendo suas folhas mais rijas do que as das plantas que receberam tratamento com solução nutritiva completa.

As plantas foram coletadas aproximadamente um mês apōs o início dos tratamentos, e o sistema radicular apresentou-se bem desenvolvido, proporcionalmente ma is desenvolvido que o das plantas sob outros tratamentos, e de coloração branca, enquanto o das plantas sob tratamento com solução completa mostrara-se acinzentado.

Essas observações estão em concordância com as de GOODALL et alii (1955), de ROORDA VAN EYSINGA et alii (1971), e com os sintomas iniciais descritos por HERNANDO e SANCHEZ CONDE (1964). 


\subsubsection{Tratamento com omissão de fósforo}

Cerca de nove dias apōs iniciados os tratamentos, as plan tas cultivadas em solução nutritiva com omissão de fósforo apresentavam o desenvolvimento severamente afetado, o que coincide com as observações de GOODALL et alii (1955), e as folhas mais rijas e eretas que as das plantas sob tratamento completo.

Após 15 dias de tratamento, as plantas deficientes en fös foro não apresentavam murchamento nas horas quentes do dia, diferentemente do ocorrido com plantas submetidas a outros tratamentos, e apōs os vinte dias constatou-se diferença na coloração das folhas mais velhas, que tornou-se verde mais clara $\left(L-7^{0}-10\right)$ que a das plantas sob tratamento completo no cultivar Brasil 48 e verde mais escuro $\left(L-7^{0}-7\right)$ no Clause's Aurēlia.

Aos 25 dias de tratamento aproximadamente as plantas mostraram-se achatadas, o que deve corresponder à "forma de roseta" descrita por ROORDA VAN EYSINGA et alii (1971) e, como estas e as observadas por GOODALL et alii (1955), não formaram cabeça, mantendo-se as folhas pequenas, rijas, abertas e eretas. As folhas mais velhas apresentaram-se lisas, semelhante ao observado por HERNANDO e SANCHEZ CONDE (1964) e amareladas $\left(L-7^{0}-10\right)$ como nas observadas por GOODALL et alii (1955).

Colhidas após 31 dias de tratamento, mostraram o sistema radicular relativamente bem desenvolvido, em relação à parte aérea, e de coloração mais escura, acinzentadas. 


\subsubsection{Tratamento com omissão de potássio}

Os primeiros sintomas decorrentes da deficiência de potássio foram notados em torno do décimo segundo dia após o inỉcio dos tratamentos, e consistiram em menor consistēncia das folhas, e maior murchamento nas horas quentes do dia.

A partir do décimo sexto dia manifestou-se alteração na coloração, que se tornou verde mais clara, principalmente no "miolo" das plantas (L-10 -11 para Brasil 48 e L-9 -13 para Clause's Aurëlia). Os bordos das folhas intermediárias e mesmo das mais novas, em alguns casos, recurvaram-se, tornando-se amarelados e depois necrosados e as folhas, deformadas. 0 murchamento continuou e a queda das fol has mais veThas tornou-se intensa.

As plantas foram colhidas no vigësimo oitavo dia apōs o início dos tratamentos, e as folhas mais velhas apresentaram amarelecimento $\left(L-9^{0}-13\right)$ do ápice, com posterior necrose, de modo semelhante ao descrito por ROORDA VAN EYSINGA et alii (1971). Os bordos laterais das fol has também apresentavam necrose.

0 sistema radicular mostrou-se escurecido, com morte de radicelas.

Os sintomas em geral foram diversos dos descritos por outros autores, năo se encontrando as folhas em forma de "coração", ou "gancho", descritas por GOODALL et alii (1955), sendo também diverso o efeito da deficiência de potássio na coloração das plantas em relação às observações de outros autores. 


\subsubsection{Tratamento com omissão de cālcio}

Os sintomas de deficiēncia de cälcio tornaram-se definidos entre seis e doze dias apös o inĩcio dos tratamentos, mostrando-se as folhas mais novas do cultivar Brasil 48 enrugadas e com pontuações escuras (marrons) bem pequenas, com diāmetro aproximado de $1 \mathrm{~mm}$. Essas pontuações localizavam-se principalmente na parte basal das folhas, prōximas às margens. No cultivar Clause's Aurēlia as folhas mais novas mos traram-se enrugadas e com äreas escurecidas (coloração $0 \gamma-6^{0}-7$ ) entre as nervuras.

Apōs cerca de 16 dias de tratamento as folhas mais novas mostraram-se enrugadas, com pontuações ou manchas escuras e recurvadas, como por menor desenvolvimento do äpice e das margens das folhas em relação ao restante da lämina foliar. Esse desenvolvimento anormal deu às folhas um aspecto semelhante ao de uma colher.

Manifestou-se também um enrolamento dos bordos das fol has mais novas e, em algumas plantas, também das mais velhas, com amarelecimento e necrose dos bordos, semelhante ao descrito por alguns autores (ROORDA VAN EYSINGA et alii, 1971).

A coloração das folhas mais velhas das plantas deficientes mostrou-se verde mais escura $\left(Y-6^{0}-6\right)$ no cultivar clause's Aur $\vec{e}-$ lia e a das folhas mais novas, mais clara $\left(Y-10^{\circ}-11\right)$.

As raizes mostraram-se de coloração marrom e, no caso do cultivar Brasil 48, necrosadas. 


\subsubsection{Tratamento com omissão de magnēsio}

As plantas submetidas a tratamento com omissão de magne-sio foram as mais tardias a apresentar sintomas de deficiēncia.

Em torno do décimo sexto dia apōs o inīcio dos tratamentos pode-se observar desenvolvimento ligeiramente inferior ao das plan tas sob tratamento completo, coloração geral mais ciara e intenso murchamento nas horas quentes do dia.

Do vigésimo dia em diante foi observado amarelecimento dos bordos das folhas ma is velhas e queda de folhas, e somente do trigésimo dia apōs o inīcio dos tratamentos em diante foi observado o sintoma característico de clorose internerval, semelhante ao descrito por HERNANDO e SANCHEZ CONDE (1964) e por ROORDA VAN EYSINGA et alii (1971).

As folhas mais velhas apresentaram coloração verde normal (semelhante às das plantas submetidas a tratamento completo) prōximo às nervuras e coloração verde clara $\left(L L Y-6^{\circ}-15\right)$ entre as nervuras.

As raizzes apresentaram-se escurecidas e, no cultivar Brasil 48, com partes necrosadas.

\subsubsection{Tratamento com omissão de enxofre}

Não foram constatados sintomas de deficiéncia. 
4.2.2. Concentração dos nutrientes

4.2.2.1. Tratamento com omissão de nitrogēnio

Os teores de nitrogênio das plantas constam da tabela 14.

Os teores das plantas sob tratamento completo situaram-

se na faixa dos valores observados pela maioria dos autores, como LORENZ e MINGES (1942), HAMILTON e BERNIER (1955), SLATER e GOODALL (1957), ZINK e YAMAGUCHI (1962). Os teores das plantas com deficiência foram semelhan tes aos obtidos por ADAMS et alii (1978) e ROORDA VAN EYSINGA et alii (1971), e inferiores aos constatados por PEREZ MELIAN et alii (1977) assi nalando-se todavia que estes referem-se a plantas que não apresentavam sintomas visuais de deficiência, não obstante mostrassem decréscimo na produção.

Os teores nas folhas e caules do cultivar Brasil 48, e nos caules do cultivar Clause's Aurēlia, foram significativamente diferentes para as plantas cultivadas em solução nutritiva completa e solução com omissão de nitrogēnio. Não se encontraram diferenças significativas nas folhas velhas do cultivar Brasil 48, bem como nas folhas e foThas velhas do cultivar Clause's Aurēlia, não obstante tenham-se manifestado sintomas de deficiēncia de nitrogênio nas plantas submetidas a tratamento com omissão desse elemento. 
Tabela 14. Teores porcentuais de nitrogēnio na matéria seca de plantas de alface, cultivadas em solução nutritiva completa $(+)$ e com omissão de nitrogēnio (-). Médias de 4 amostras

\begin{tabular}{llllllll}
\hline \multirow{2}{*}{ Cultivar } & \multicolumn{2}{c}{ Folhas } & \multicolumn{2}{c}{ Folhas velhas } & \multicolumn{2}{c}{ Caules } \\
\cline { 2 - 8 } & $+\mathrm{N}$ & $-\mathrm{N}$ & $+\mathrm{N}$ & $-\mathrm{N}$ & $+\mathrm{N}$ & $-\mathrm{N}$ \\
\hline \multirow{2}{*}{ Brasil 48} & 3,37 & 1,86 & 0,98 & 1,03 & 2,00 & 0,82 \\
C. Aurēlia & 3,02 & 2,68 & 1,27 & 0,98 & 1,61 & 0,67
\end{tabular}

\begin{tabular}{|c|c|c|c|}
\hline & & Brasil 48 & Clause's Aurēlia \\
\hline \multicolumn{2}{|c|}{ F. A. tratamentos } & $60,63 \star \star$ & $7,96 * \star$ \\
\hline \multicolumn{2}{|c|}{ B. partes da planta } & $72,92 \star \star$ & $38,11 * *$ \\
\hline \multicolumn{2}{|l|}{$A \times B}$. & $17,62^{\star \star \star}$ & n.s. \\
\hline DMS $(1 \%)$ & A. tratamentos & 0,3261 & 0,53 \\
\hline \multirow[t]{2}{*}{ (Tukey) } & B. partes da planta & 0,46 & 0,75 \\
\hline & $A \times B$ & 0,78 & 1,27 \\
\hline \multirow[t]{3}{*}{ DMS $(5 \%)$} & A. tratamentos & & 0,39 \\
\hline & B. partes da planta & & 0,58 \\
\hline & $A \times B$ & & 1,02 \\
\hline
\end{tabular}


4.2.2.2. Tratamento com omissão de fösforo

Para os dois cultivares as diferenças observadas no teor de fósforo das plantas cultivadas em solução nutritiva completa e com omissão de fösforo foram significativas, como se pode ver pelos dados da tabela 15 .

Os niveis encontrados nas plantas com deficiência foram semelhantes aos observados por GRANT LIPP e GOODALL (1958) e por ROORDA VAN EYSINGA et alii (1971). Situaram-se abaixo do nível crítico $10,2 \%$ de fósforo) definido por ZINK e YAMAGUCHI (1962) e foram semelhantes aos obtidos em plantas deficientes por HERNANDO e SANCHEZ CONDE (1964) e por PEREZ MELIAN et alii (1977).

As plantas do cultivar Brasil 48 submetidas a tratamento com solução nutritiva completa apresentaram teores semelhantes aos observados em plantas sadias por GRANT LIPP e GOODALL (1958) e por ROORDA VAN EYSINGA et alii (1971). Jà o cultivar Clause's Aurēlia apresentou nas plantas normais teores mais elevados, superiores aos da maioria dos autores, pröximos ao mais alto teor encontrado por PANDITA e ANDREW (1967) e inferiores apenas aos observados por SANCHEZ CONDE (1980).

\subsubsection{Tratamento com omissão de potássio}

Os teores de potässio encontrados na matéria seca de plantas de alface do ensaio conduzido em casa de vegetação e sob tratamento com solução nutritiva completa foram, para o cultivar Brasil 48, 1 i geiramente inferiores aos observados no campo e, para o cultivar Clause's 
Tabela 15. Teores porcentua is de fösforo na matéria seca de plantas de alface, cultivadas em solução nutritiva completa $(+)$ e com omissão de fósforo $(-)$. Médias de 4 amostras

\begin{tabular}{|c|c|c|c|c|c|c|c|}
\hline \multirow{2}{*}{\multicolumn{2}{|c|}{ Cultivar }} & \multicolumn{2}{|c|}{ Fol has } & \multicolumn{2}{|c|}{ Folhas velhas } & \multicolumn{2}{|c|}{ Caules } \\
\hline & & $+\mathrm{p}$ & $-p$ & $+P$ & $-P$ & $+P$ & $-P$ \\
\hline \multicolumn{2}{|l|}{ Brasil 48} & 0,44 & 0,16 & 0,12 & 0,09 & 0,34 & 0,10 \\
\hline \multirow[t]{2}{*}{ Clause's } & Aurēlia & 0,71 & 0,19 & 0,32 & 0,14 & 0,91 & 0,17 \\
\hline & & & & Brasil 48 & & Clause's & rélia \\
\hline \multicolumn{3}{|c|}{ F. A. tratamentos } & & \multicolumn{2}{|l|}{$374,23 * \star$} & \multicolumn{2}{|c|}{$127,01 * \star$} \\
\hline \multicolumn{3}{|c|}{ B. partes da planta } & & \multicolumn{2}{|l|}{$142,86 \star \star$} & \multicolumn{2}{|c|}{$19,11 * \star$} \\
\hline \multicolumn{3}{|l|}{$A \times B$} & & \multicolumn{2}{|l|}{$64,63 \star \star$} & \multicolumn{2}{|c|}{$14,74 * \star$} \\
\hline \multirow[t]{3}{*}{ DMS $(1 \%)$} & A. tratar & mentos & & \multicolumn{2}{|l|}{0,027} & \multicolumn{2}{|c|}{0,12} \\
\hline & B. partes & s da pl & nta & \multicolumn{2}{|l|}{0,038} & \multicolumn{2}{|c|}{0,17} \\
\hline & $A \times B$ & & & \multicolumn{2}{|l|}{0,065} & \multicolumn{2}{|c|}{0,29} \\
\hline \multicolumn{4}{|c|}{ DMS (5\%) A. tratamentos } & & & \multicolumn{2}{|c|}{0,0890} \\
\hline & B. partes & $\mathrm{s}$ da $\mathrm{pl}$ & nta & & & \multicolumn{2}{|c|}{0,1319} \\
\hline & $A \times B$ & & & & & \multicolumn{2}{|c|}{0,2326} \\
\hline
\end{tabular}


Aurēlia, semelhantes.

Os teores estiveram, em ambos os ensaios, situados

na

faixa observada pela maioria dos autores, como LORENZ e MINGES(1942), LAMBETH (1953), HARWARD et alii (1955), HAMILTON e BERNIER (1958), ZINK e YAMAGUCHI (1962), HERNANDO e SANCHEZ CONDE (1964), FERNANDES et alii (1971), PEREZ MELIAN et alii (1971), ADAMS et alii (1978), SANCHEZ CONDE e AZUARA (1980).

Os teores encontrados nas plantas com deficiēncia foram in feriores aos das plantas sob tratamento completo e as diferenças foram significativas. Os teores de potāssio das plantas com deficiēncia foram semelhantes aos obtidos por ROORDA VAN EYSINGA et alii (1971) e PEREZ MELIAN et alii (1971), e inferiores aos observados por HERNANDO e SANCHEZ CONDE (1964). Os teores encontram-se na tabela 16.

4.2.2.4. Tratamento com omissão de cālcio

Os teores de cálcio das plantas submetidas a tratamento com solução nutritiva completa foram semelhantes aos observados por LORENZ e MINGES (1942), HARWARD et alii (1955), ZINK e YAMAGUCHI (1962), FERNANDES et alii (1971), ROORDA VAN EYSINGA et alii (1971), PEREZ MELIAN et alii (1977), SANCHEZ CONDE (1980) e SANCHEZ CONDE e AZUARA (1980)e superiores aos encontrados por BEAR et alii (1949) e CAROLUS (1975).

Os teores de cálcio das plantas submetidas a tratamento com omissão de cálcio foram significativamente inferiores aos das plantas sob tratamento completo, e semelhantes aos encontrados em plantas 
Tabela 16. Teores porcentuais de potássio na matéria seca de plantas de alface cultivadas em solução nutritiva completa $(+)$ e com omissão de potássio (-). Médias de 4 amostras

\begin{tabular}{lcccccc}
\hline \multirow{2}{*}{ Cultivar } & \multicolumn{2}{c}{ Folhas } & \multicolumn{2}{c}{ Folhas velhas } & \multicolumn{2}{c}{ Caule } \\
\cline { 2 - 7 } & $+\mathrm{K}$ & $-\mathrm{K}$ & $+\mathrm{K}$ & $-\mathrm{K}$ & $+\mathrm{K}$ & $-\mathrm{K}$ \\
\hline \multirow{2}{*}{ Brasil 48 } & 5,54 & 1,32 & 6,02 & 2,17 & 2,53 & 0,67 \\
C. Aurēlia & 7,77 & 1,54 & 6,34 & 3,23 & 6,13 & 1,10 \\
\hline
\end{tabular}

Brasil 48

F. A. tratamentos

B. partes da planta

$A \times B$

DMS (1\%) A. tratamentos

(Tukey)

B. partes da planta $468,52^{\star \star}$

$95,09 \star \star$

$22,89 \star \star$

0,44

0,62

1,05
Clause's Aurēlia

$317,76^{\star \star}$

7,63 **

$11,41^{\star *}$

$A \times B$

1,05


com deficiência por VLAMIS (1949) e ROORDA VAN EYSINGA et alii (1971), e inferiores aos determinados por HERNANDO e SANCHEZ CONDE (1964) e por PEREZ MELIAN et alii (1977). Estes ūltimos autores consideraram que anālises foliares não poderiam ser usadas para determinar deficiēncia leve de călcio, pois os teores encontrados foram semelhantes aos das plantas normais, havendo diferença apenas na produtividade. No caso de deficiência acentuada os sintomas visiveis tornaram desnecessäria a anālise foliar.

0s teores de cálcio das plantas normais e com deficiēncia encontram-se na tabela 17.

\subsubsection{Tratamento com omissão de magnēsio}

Os teores de magnësio encontrados nas plantas normais, submetidas a tratamento completo, foram semelhantes aos observados por BEAR et alii (1949), em levantamento realizado nos EUA, ligeiramente superiores aos observados por FERNANDES et alii (1971) e por SANCHEZ CONDE e AZUARA (1980) e estiveram na faixa observada por ZINK e YAMAGUCHI (1962) e pela maioria dos autores.

Os teores das plantas com deficiēncia foram significativamente inferiores aos encontrados nas plantas normais, e inferiores aos observados em plantas com deficiēncia por HERNANDO e SANCHEZ CONDE (1964) e por ROORDA VAN EYSINGA et alii(1971).

Os dados referentes à concentração de magnésio nas plantas encontram-se na tabela 18. 
Tabela 17. Teores porcentuais de cálcio na matéria seca de plantas de alface, cultivadas em solução nutritiva completa $(+)$ e com omissão de cālcio (-). Médias de 4 amostras.

\begin{tabular}{llllllll}
\hline \multirow{2}{*}{ Cultivar } & \multicolumn{2}{c}{ Folhas } & \multicolumn{2}{c}{ Folhas velhas } & \multicolumn{2}{c}{ Caule } \\
\cline { 2 - 8 } & $+\mathrm{Ca}$ & $-\mathrm{Ca}$ & $+\mathrm{Ca}$ & $-\mathrm{Ca}$ & $+\mathrm{Ca}$ & $-\mathrm{Ca}$ \\
\hline \multirow{2}{*}{ Brasil 48 } & 0,97 & 0,20 & 1,94 & 1,19 & 0,36 & 0,09 \\
Clause's Aurēlia & 1,47 & 0,31 & 2,59 & 1,37 & 0,59 & 0,09 \\
& & & & & & \\
\hline
\end{tabular}

Brasil $48 \quad$ Clause's Aurēlia

F A. tratamento

$84,44^{* *}$

$209,19 * *$

B. partes da planta

154,06 **

211,54 **

$A \times B$

$6,38^{\star \star}$

$12,40^{\star *}$

DMS (1\%) A. tratamento

0,19

0,19

(Tukey)

B. partes da planta

0,26

0,27

$A \times B$

0,44

0,45 
Tabela 18. Teores de magnésio na matéria seca de plantas de alface, cultivadas em solução nutritiva completa e com omissão de magnësio $(\%)$. Médias de 4 amostras

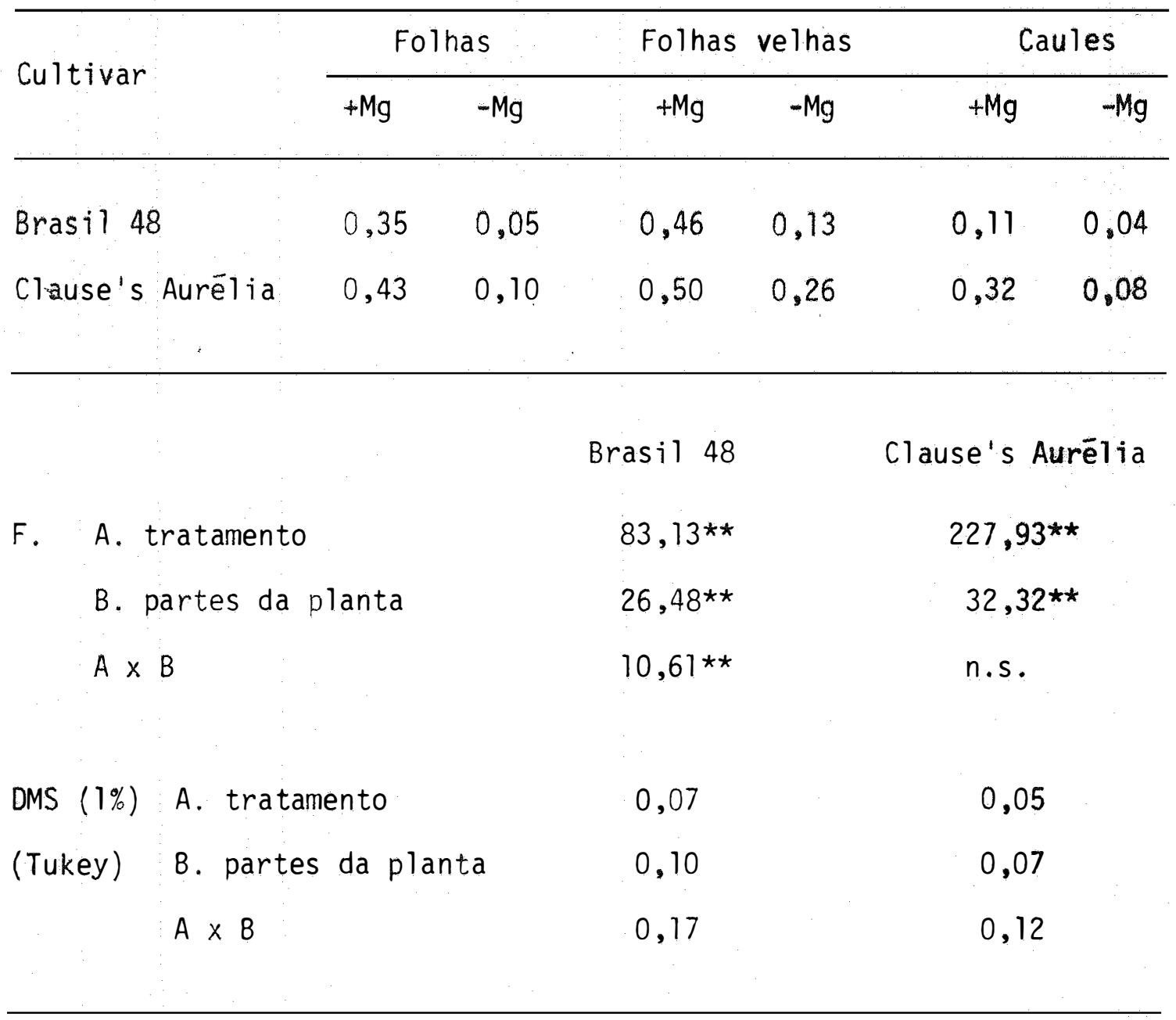


4.2.2.6. Tratamento com omissão de enxofre

Não foram encontradas diferenças significativas entre os teores de enxofre das plantas submetidas a tratamento com solução completa e os das plantas submetidas a tratamento com omissão de enxofre, como se pode observar através da tabela 19.

Os teores de enxofre encontrados foram inferiores aos determinados por FERNANDES et alii (1971) para plantas normais. A concentração de enxofre no cultivar Clause's Aurēlia foi semelhante à en- contrada por PEREZ MELIAN et alii (1977) em plantas normais e esteve entre os teores considerados como pertencentes a plantas com deficiência por ROORDA VAN EYSINGA et alii(1971). A concentração no cultivar Brasil 48 foi semelhante à observada em plantas com deficiēncia por PEREZ MELIAN et alii (1977) e por ROORDA VAN EYSINGA et alii(1971). 
Tabela 19. Teores de enxofre na matēria seca de plantas de alface, cultivadas em solução nutritiva completa e com omissão de enxofre (\%). Médias de 4 amostras

\begin{tabular}{lccccccc}
\hline \multirow{2}{*}{ Cultivar } & \multicolumn{2}{c}{ Folhas } & \multicolumn{2}{c}{ Folhas velhas } & \multicolumn{2}{c}{ Caules } \\
\cline { 2 - 8 } & $+S$ & $-S$ & $+S$ & $-S$ & $+S$ & $-S$ \\
\hline Brasil 48 & 0,16 & 0,16 & 0,08 & 0,09 & 0,10 & 0,09 \\
Clause's Aurēiia & 0,24 & 0,25 & 0,15 & 0,12 & 0,14 & 0,09 \\
\hline
\end{tabular}

Brasil 48

Clause's Aurētia
F. A.tratamento
n.s.
n.s.
B.partes da planta
$6,84 *$
$5,47 *$
$A \times B$
n.s.
n.s.

DMS (1\%)
(Tukey)

A. tratamento $\quad 0,05$

0,09

B. partes da planta

0,07

0,14

$A \times B$

0,12

0,23

DMS (5\%)

A. tratamento

0,03

0,07

(Tukey)

B. partes da planta

0,05

0,11

$A \times B$

0,09

0,23 


\section{OBSERVAÇOEES GERAIS}

Considerando-se que a cultura de alface, nas regiões pro dutoras, è repetida consecutivamente na mesma gleba, a extração anual de nutrientes é bastante elevada, podendo ser estimada em cerca de quatro a cinco vezes a obtida neste trabalho para uma cultura.

Destaca-se a elevada acumulação de potāssio em relação aos demais nutrientes, e o baixo acūmulo de enxofre $(2 \mathrm{~kg} / \mathrm{ha})$, que explica a não ocorrēncia de deficiēncia deste elemento nas plantas sob tratamento com omissão desse nutriente.

Chama atenção igualmente a elevada extração de cālcio pe los cultivares que normalmente estão sujeitos a intensa irrigação e cau sando lixiviação deste elemento no solo. Suspeita-se que possa ocorrer com certa frequēncia deficiēncia deste nutriente em condições de campo.

A acumulação tanto de macro como de micronutrientes foi diferente nos cultivares mostrando-se o cultivar Brasil 48 mais exigente, principalmente em potāssio, cobre, ferro, manganēs e zinco. (tabelas 20 e 21 ). 

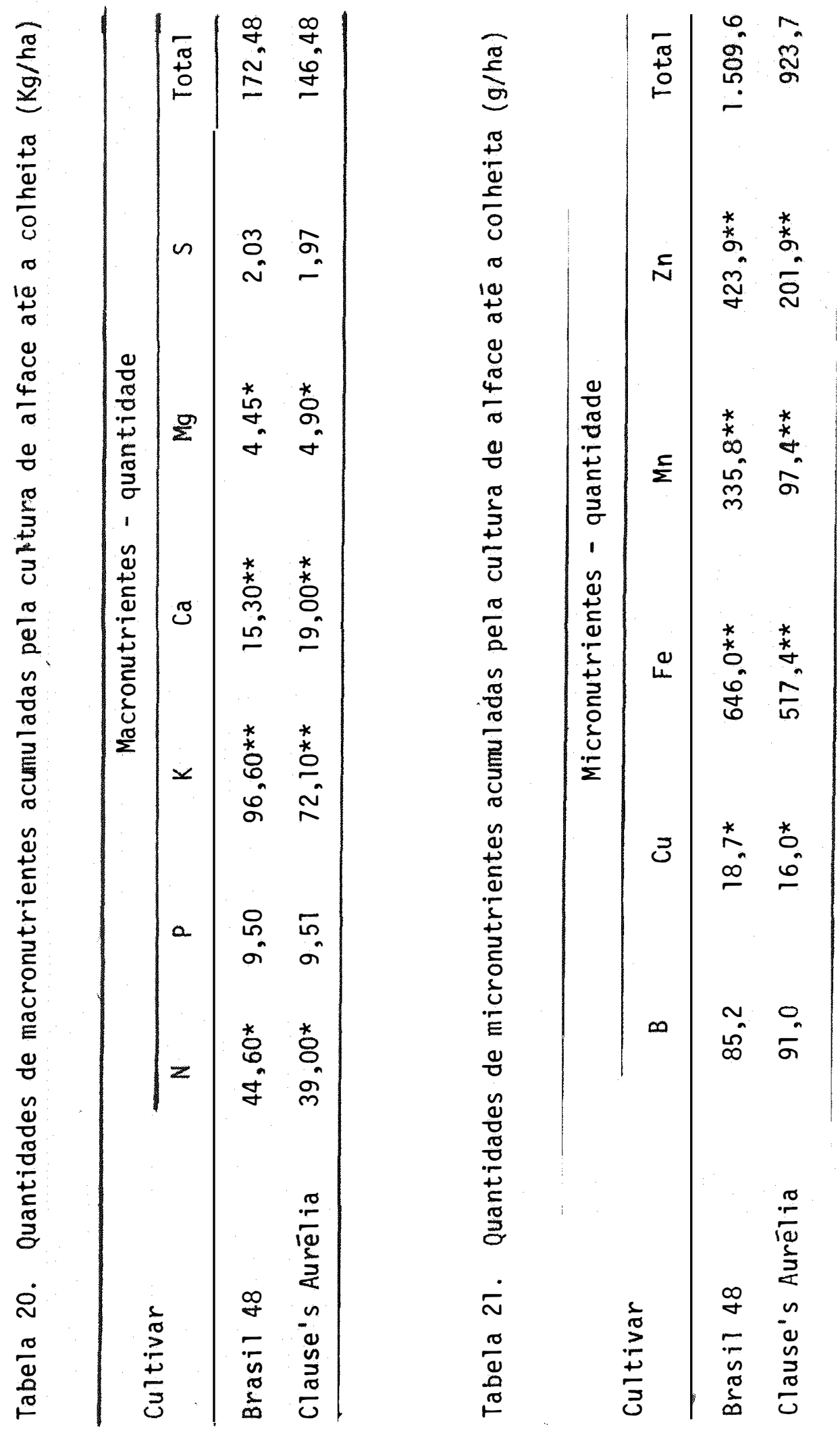
O cultivar Brasil 48 mostrou elevada capacidade de acumulação de manganês, sendo interessante no futuro, estudo mais detalhado de seu comportamento em relação a esse elemento, jā que diversos autores constataram ocorrência de toxicidade de manganès em culturas de alface e foi levantada a hipótese de sua ocorrência em condições ao Estado de São Paulo*.

Seriam ūteis iqualmente trabalhos visando a identificação da fase de "fome oculta" mediante a aplicação do teste rápido. Dados de PEREZ MELIAN et alii (1977) mostram a ocorrência de diminuição nas produções anterior ao aparecimento de sintomas.

* Hiroshi Nagai, Instituto Agronômico do Estado de São Paulo, Campinas, SP. Comunicação pessoal. 


\section{CONCLUSOEES}

\subsection{Ensaio de campo}

\subsubsection{Produção de matëria seca}

- Não houve diferença significativa entre os cultivares Brasil 48 e Clause's Aurélia na produção de matéria seca.

- O crescimento foi lento no início, sofrendo aceleração a partir dos 30 dias.

- O cultivar Brasil 48 apresentou taxas de incorporação de matēria seca crescentes atē a colheita, e o cultivar Clause's Aurēlia uma taxa máxima entre o 510 e 0620 dia.

- As taxas máximas de produção de matéria seca foram 0,484 e 0,402 gramas por planta por dia, para os cultivares Brasil 48 e Clause's Aurēlia, respectivamente.

- Para o cultivar Brasil 48,66\% da matéria seca foi incorporada nos 20 dias que antecederam a colheita, e 38\% nos ūltimos dez 
dias. Para o cultivar Clause's Aurélia os valores foram $59 \%$ e $27 \%$.

- A produção de matéria seca foi de $12,75 \mathrm{~g} / \mathrm{planta}$ para o cultivar Brasil 48 e de $12,52 \mathrm{~g} / \mathrm{planta}$ para o cultivar Clause's Aurélia e de aproximadamente $1200 \mathrm{Kg} / \mathrm{ha}$, para uma população teōrica de 95000 plantas/ha, para ambos os cultivares.

\subsubsection{Acumulação de nutrientes}

- A acumulação de nutrientes acompanhou, em linhas gerais a produção de matéria seca, sendo lenta no início e sofrendo aceleração a partir dos 30 dias.

- Os cultivares Brasil 48 e Clause's Aurélia apresentaram diferenças significativas na acumulação de nitrogēnio, potāssio, cālcio, magnésio, cobre, ferro, manganès e zinco, sendo a acumulação de fösforo, enxofre e boro, semelhante para os dois cultivares.

- O cultivar Brasil 48 foi mais exigente na acumulação de nitrogènio, potássio, cobre, ferro, manganès e zinco do que o cultivar Clause's Aurēlia. Este foi mais exigente em cálcio e magnésio.

- Nos últimos vinte dias da cultura foram absorvidos entre 50 e $69 \%$ do total acumulado de cada nutriente, para o cultivar Brasil 48 , e entre 43 e $65 \%$ do total para o cultivar Clause's Aurēlia.

- A absorção de nutrientes foi contínua, não sendo atingido ponto de máxima acumulação para nenhum nutriente atē a colheita. 
- As quantidades de macro e micronutrientes acumuladas por planta do cultivar Brasil 48 foram: $469 \mathrm{mg}$ de nitrogēnio, $100 \mathrm{mg}$ de fösforo, $1017 \mathrm{mg}$ de potāssio, $161 \mathrm{mg}$ de cālcio, $47 \mathrm{mg}$ de magnēsio e $21 \mathrm{mg}$ de enxofre, $896 \mu \mathrm{g}$ de boró, $196 \mu \mathrm{g}$ de cobre, $6800 \mu \mathrm{g}$ de ferro, $3534 \mu \mathrm{g}$ de manganès e $4462 \mu \mathrm{g}$ de zinco.

- As quantidades de macro e micronutrientes acumuladas por planta do cultivar Clause's Aurēlia foram: $410 \mathrm{mg}$ de nitrogènio, $100 \mathrm{mg}$ de fósforo, $759 \mathrm{mg}$ de potāssio, $200 \mathrm{mg}$ de cāicio, $52 \mathrm{mg}$ magnēsio, $21 \mathrm{mg}$ de enxofre, $958 \mu \mathrm{g}$ de boro, $168 \mu \mathrm{g}$ de cobre, $5446 \mu \mathrm{g}$ de ferro; $1025 \mu \mathrm{g}$ de manganês e $2425 \mu \mathrm{g}$ de zinco.

\subsection{Ensaio realizado em casa de vegetação}

\subsubsection{Sintomas de deficiēncia de macronutrientes}

- As deficiências de nutrientes nos cultivares de alface estudados se traduziram por sintomas típicos e facilmente identificāveis, com excessão do enxofre, para o qual não foram obtidos sintomas de carēncia.

\subsubsection{Concentração de nutrientes nas plantas}

- As concentrações de nutrientes nas folhas (excluidas as folhas velhas) de alface provenientes de plantas normais do cultivar Brasil 48 foram significativamente diferentes dos teores encontrados nas plantas com deficiência. Os teores foram, para plantas normais e com 
deficiēncia: de nitrogēnio: 3,37 e $1,86 \%$; de fósforo: 0,44 e $0,16 \%$; de potāssio: 5,54 e 1,32\%; de cālcio: 0,97 e 0,20\%; de magnésio: 0,35 e $0,05 \%$. Os teores de enxofre foram $0,16 \%$, não se constatando deficiēncia.

- As concentrações de fösforo, potássio, cálcio e magnēsio nas folhas de alface provenientes de plantas normais do cultivar Clause's Aurélia foram significativamente diferentes dos teores encontrados nas plantas com deficiência. Os teores foram, para plantas normaìs e com deficiência: de fósforo: 0,71 e 0,19\%; de potāssio: 7,7 e 1,54\%; de cálcio: 1,47 e $0,31 \%$; de magnésio: 0,43 e $0,10 \%$. Os teores de enxofre foram 0,24 e $0,25 \%$, não se constatando deficiência. Não obstante manifestarem sintomas de deficiēncia, as plantas submetidas a tratamento com omissão de nitrogênio apresentaram teores $(2,68 \%)$ estatisticamente semelhantes aos das plantas norma is $(3,02 \%)$. 
ADAMS, P.; C.J.GRAVES e G.W. WINDSOR. 1978. Some responses of lettuce, grown in beds of peat, tonitrogen, potassium and molybdenum. Journal. of Hort.Science $53(4): 275-281$.

BEAR, F.E.; S.J.TOTH e A.L.PRINCE. 1949. Variation in Mineral Composition of Vegetables. Proceedings of the Soil Science Society of America. 13:380-384.

CAROLUS, R. 1975. Calcium relationships in vegetable nutriton and quality. Communications in Soil Science and Plant Analysis. 6(3): 285-298.

ESTHER STRUCKMEYER, B. e T.W.TIBBITS. 1965. Anatomy of lettuce leaves grown with a complete nutrient supply and without calcium or boron. Proceedings of the American Society for Hort.Sciences. 87:321-329. 
FERNANDES, P.D.; G.D.de OLIVEIRA e H.P.HAAG. 1971. Nutrição Mineral de Hortaliças. XIV. Absorção de Macronutrientes pela Cultura da Alface. Revista "0 Solo". Ano LXIII(2):7-10.

GARDNER, B.R. e W.D.PEW. 1979. Comparison of various nitrogen sources for the fertilization of winter-grown head lettuce. Journal of American Society of Hort.Science, 103(4):534-536.

GOODALL, D.W.; A.E.GRANT LIPP e W.G.SLATER. 1955. Nutrient INteractions and deficiency diagnosis in the lettuce. 1. Nutritional interaction and growth. Australian Journal of Biological Sciences. 8:301-329.

GRANT LIPP, A.E. e D.W.GOODALL. 1958. Nutrient interactions and deficiency diagnosis in the lettuce. IV. Phosphorus content and response to phosphorus. Australian Journal of Biological Sciences. $11: 30-44$.

HAMILTON, H.A. e R.BERNIER, 1955. N.P.K. fertilizer effects on yield, composition and residues of lettuce, celery, carrot and onion grown on an organic soil in Quebec. Canadian Journal of Plant Science. 55 (2):453-461.

HARWARD, M.E.; W.A. JACKSON, W.L.LOTT E D.D.MASON. 1955. Effects of Al, Fe e Mn upon the growth and Composition of lettuce. Proceedings. of the American Society for Horticultural Science, 66:261-266. 
HERNANDO, V. E M.P.SANCHEZ CONDE. 1964. Estudio de deficiências minerales en el cultivo de lechuga romana. Anales de Edafologia y Agrobiologia. 23:769-776.

LAMBETH, V.N. 1953. Variable Potassium and magnesium saturation on Growth and Mineral Composition of Bibb Lettuce. Proceedings of the American Society for Horticultural Science. 62:357-362.

LEH, H.0. 1970. Investigations on tipburn of lettuce with special reference to nutrient uptake. Nachr B1, dtsch. PfI Sch Dierist., Braunschweig, 22:86-9.

LORENZ, O.A. e P.A.MINGES, 1942. Nutrient Absorption by a Summer Crop of Lettuce in Salinas Valley, California. Proceedings of the American Society for Horticultural Science, 40:523-527.

MIDGLEY, A.R. e D.E.DUNKLEE. 1946. Boron deficience of lettuce. Better. crops with Plant Food. 30(2):17-20.

NISHIMOTO, D.K.; R.L.FOX e P.E.PARVIN. 1977. Response of vegetable crops to phosphorus concentrations in soil solution. Journal of American Society for Horticultural Science, 102(6):705-709.

PANDITA, M.L. e W. T.ANDREW. 1967. A correlation between phosphorus content of leaf tissue and days to maturity in tomato and lettuce. 
Proceedings of the American Society for Horticultural Science. 91: $544-549$.

PARUPS, E.V. 1958. Nutrition of lettuce with nitrogen, phosphorus and potassium on organic soils in Ontario. Proceedings of the American Society for Horticultural Science. 71:399-406.

PEREZ MELIAN, G.; A.L.ESGALONA e A.A.STEINER, 1977. Leaf analysis as a diagnosis of nutritional deficiency or excess in the soilless culture of lettuce. plant and Soil. 48:259-267.

RANZANI, G.; 0.FREIRE e T.KINJ0, 1966. Carta de Solos do Municipio de Piracicaba. Piracicaba, Centro de Estudos de Solos, 85 p.

ROORDA VAN EYSINGA, J.P.N.L. e K.W.SMILDE. 1971. Nutritional disorders in glasshouse lettuce, Centre for Agricultural publishing and documentation, Wageningen, Holanda, 56p.

SANCHEZ CONDE, Ma.P. 1980. Evaluation de los efectos del medio nutritivo con bajo contenido en calcio sobre la planta de lechuga. Anales. de Edafologia y Agrobiologia. 39:975-988.

SANCHEZ CONDE, Ma.P. e P.AZUARA. 1980. Distribucion de nutrientes en plantas de lechuga sometidas a diferentes concentraciones de magnesio. Anales de Edafologia y Agrobiologia. 39:999-1008. 
SARRUGE, J.R. 1970. Prāticas de nutrição e adubação das plantas cultivadas (mimeogr.) Depto. de Química, E.S.A."Luiz de Queiroz", USP, Piracicaba, São Paulo.

SARRUGE, J.R. e H.P.HAAG (1974). Anālises Quîmicas em plantas. Depto. de Quĩmica, E.S.A."Luiz de Queiroz", USP, Piracicaba, São Paulo.

SETZER, J. 1946. Contribuição para o Estudo do Clima do Estado de São Paulo. Escolas Professores Salesianos, São Paulo. 239p.

SLATER, W.G. e D.W.GOODALL. 1957. Nutriente Interactions and Deficiency Diagnosis in the lettuce. III. Nitrogen content and response to nitrogen. Australian Journal of Biological Sciences. 10:253-278.

SMITH, R. e M.A.SCAIFE, 1972. The phosphorus requirement of lettuce. 1. Use of $P$ intensity estimates to predict the response curve. The Journal of Agricultural Science. $80: 111-117$.

THIBODEAU, P.0. e P.L.MINOTTI. 1969. The influence of calcium on the development of lettuce tipburn. Journal of the American Society for Horticul tural Science. 94:372-375.

TIBBITS, T.W.; B.ESTHER STRUCKMEYER E R.RAMA RAO. 1965. Tipburn of lettuce as related to release of latex. Proceedings of the American. Society for Horticultural Science, 86:462-467. . 
VLAMIS, J. 1949. Growth of lettuce and barley as influenced by degree of calcion saturation of soil. Soil science, 67:453-466.

WOODMAN, R.M. 1939. Studies in the nutrition of vegetables. The effects of variation in the nitrogen supply on lettuce (var. Mayking) in sand culture. Annals of Botany. 3: 649-656.

WOODMAN, R.M. 1940. The nutrition of lettuces grown as cultures under glass. The annals of applied biology. 27:5-16.

WUTKE, A.C.P. 1972. Anālise Quîmica na avaliação da fertilidade. In: MONIZ, A.C. (Coord.), Elementos de Pedologia. Ed. Polígono, Ed. USP, São Paulo, p.223-29.

ZINK, F.W. EM. YAMAGUCHI, 1962. Studies on the Growth rate and nutrient absorption of head lettuce. Hilgardia, 32(11):471-500. 